\title{
Article \\ The Lrp/AsnC-Type Regulator PA2577 Controls the EamA-like Transporter Gene PA2576 in Pseudomonas aeruginosa
}

\author{
Magdalena Modrzejewska, Adam Kawalek (D) and Aneta Agnieszka Bartosik * (D) \\ Institute of Biochemistry and Biophysics, Polish Academy of Sciences, 02-106 Warsaw, Poland; \\ magda.modrzejewska@ibb.waw.pl (M.M.); a.kawalek@ibb.waw.pl (A.K.) \\ * Correspondence: anetab2@ibb.waw.pl
}

check for updates

Citation: Modrzejewska, M.; Kawalek, A.; Bartosik, A.A. The Lrp/AsnC-Type Regulator PA2577 Controls the EamA-like Transporter Gene PA2576 in Pseudomonas aeruginosa. Int. J. Mol. Sci. 2021, 22, 13340. https://doi.org/10.3390/ ijms222413340

Academic Editors: Luca Agnelli and Giovanni Malerba

Received: 10 November 2021 Accepted: 10 December 2021 Published: 12 December 2021

Publisher's Note: MDPI stays neutral with regard to jurisdictional claims in published maps and institutional affiliations.

Copyright: (C) 2021 by the authors. Licensee MDPI, Basel, Switzerland. This article is an open access article distributed under the terms and conditions of the Creative Commons Attribution (CC BY) license (https:/ / creativecommons.org/licenses/by/ $4.0 /)$.

\begin{abstract}
The regulatory network of gene expression in Pseudomonas aeruginosa, an opportunistic human pathogen, is very complex. In the PAO1 reference strain, about $10 \%$ of genes encode transcriptional regulators, many of which have undefined regulons and unknown functions. The aim of this study is the characterization of PA2577 protein, a representative of the Lrp/AsnC family of transcriptional regulators. This family encompasses proteins involved in the amino acid metabolism, regulation of transport processes or cell morphogenesis. The transcriptome profiling of $P$. aeruginosa cells with mild PA2577 overproduction revealed a decreased expression of the PA2576 gene oriented divergently to $P A 2577$ and encoding an EamA-like transporter. A gene expression analysis showed a higher mRNA level of PA2576 in P. aeruginosa $\triangle P A 2577$, indicating that PA2577 acts as a repressor. Concomitantly, ChIP-seq and EMSA assays confirmed strong interactions of PA2577 with the PA2577/ PA2576 intergenic region. Additionally, phenotype microarray analyses indicated an impaired metabolism of $\triangle P A 2576$ and $\triangle P A 2577$ mutants in the presence of polymyxin $\mathrm{B}$, which suggests disturbances of membrane functions in these mutants. We show that PA2576 interacts with two proteins, PA5006 and PA3694, with a predicted role in lipopolysaccharide (LPS) and membrane biogenesis. Overall, our results indicate that PA2577 acts as a repressor of the PA2576 gene coding for the EamA-like transporter and may play a role in the modulation of the cellular response to stress conditions, including antimicrobial peptides, e.g., polymyxin B.
\end{abstract}

Keywords: Pseudomonas aeruginosa; Lrp/AsnC transcriptional regulators; RNA-seq; ChIP-seq; PA2577 regulon; EamA-like transporter

\section{Introduction}

The Lrp/AsnC family of transcriptional regulators comprises an important group of factors with diverse regulatory functions. The name of the family derives from 'leucineresponsive regulatory protein' (Lrp) from Escherichia coli and its paralogue-the AsnC protein. Lrp is one of the best-studied bacterial transcriptional regulators which acts as a global factor, considered to control the expression of almost 30\% of all E. coli genes [1,2]. Lrp action is influenced by leucine and leads to the activation or repression of the transcription of genes affecting a variety of cellular processes, such as amino acid synthesis, the transport of molecules or the formation of pili [2].

The AsnC protein from E. coli is a local regulator activating an asnA gene that codes for asparagine synthetase $\mathrm{A}$, simultaneously auto-repressing its own gene [3]. The stimulation of $a s n A$ transcription by AsnC is reduced in the presence of asparagine, being a final product of AsnA action, which represents a classical negative feedback mechanism. Although Lrp and AsnC are probably evolutionarily related (a 25\% identity of amino acid sequences), they act divergently, demonstrating an extremely global or specific control [4]. Hence, members of the Lrp/AsnC family of transcriptional regulators may influence cellular metabolism in a global or specific manner, with the second mode of action being dominant among currently characterized Lrp/AsnC-like proteins [5-9]. 
Lrp/AsnC-type regulators are also known as 'feast/famine regulatory proteins' (FFRPs), due to the understanding of their regulatory properties as an adaptation for survival in nutrient-rich or depleted environments [10]. Examples of similarly functioning proteins are widespread in the literature, e.g., PutR from Agrobacterium tumefaciens affected by proline, Grp from Zymomonas mobilis influenced by glutamate, or MdeR from Pseudomonas putida altered by L-methionine [8,11,12].

It has been confirmed by electron microscopy that FFRPs form multimeric assemblies in the presence of genomic DNA [13]. Best characterized representatives of the family form octamers consisting of four dimers [14-20]. However, other structures of FFRPs have also been described, such as a cylinder formed by six dimers [13]. Both the structures of the regulator and its activation/repression properties can be modulated by a "feast" and "famine" mode, depending on the ligand/effector availability [21,22].

Pseudomonas aeruginosa is a pathogen capable of infecting a variety of hosts, including immunocompromised people, and is the object of extensive studies because of its adaptability, allowing survival in different environments. It has previously been reported that $P$. aeruginosa transcriptome is directed by a complex network of direct and indirect links, in which transcriptional regulators comprise a crucial group controlling most cellular processes in response to environmental conditions [23,24]. The high number of genes encoding transcriptional factors belonging to different families (491 genes in the PAO1 reference strain, which represents about $10 \%$ of the genome) may provide proof of their importance in P. aeruginosa cells. The complexity of gene expression regulation in P. aeruginosa can be exemplified by the regulatory network controlling virulence or biofilm formation [25].

There are nine genes encoding Lrp/AsnC-like regulators in the PAO1. Among them, only three have a clarified function. The Lrp protein (PA5308), also known as DadR, is involved in the catabolism of L-alanine and several D-amino acids, regulating the dadAX operon. The $d a d A$ and $d a d X$ genes code for the D-amino acid dehydrogenase DadA and the amino acid racemase DadX, respectively. DadR is required for the transcriptional activation of $\operatorname{dad} A X$ and as such induction is enhanced by the presence of intracellular L-alanine [26,27].

The second previously characterized Lrp/AsnC-like regulator from P. aeruginosa, KynR (PA2082), directly controls the kynBU operon, divergently transcribed to the kynR encoding two crucial enzymes of the kynurenine pathway. Kynurenine is a product of tryptophan breakdown, which is converted into anthranilate and intermediates of central metabolism or aromatic compounds. Apart from P. aeruginosa, such a pathway of tryptophan catabolism is only present in a small group of bacteria, e.g., Ralstonia eutropha or Bordetella pertussis, and KynR is highly conserved among them [28].

The transcriptional regulator BkdR (PA2246) is the last member from the family with a known function in P. aeruginosa so far. Similarly, as Lrp and KynR, it is also engaged in the control of metabolic processes. BkdR is an activator of the four-gene $b k d$ operon divergently transcribed to the $b k d R$. The $b k d A 1, b k d A 2, b k d B$ and $l p d V$ genes encode an enzyme complex involved in the metabolism of valine, leucine and isoleucine by the catalysis of the branched-chain keto acids decarboxylation. The expression of the $b k d$ operon is probably stimulated by the presence of these amino acids, which may act as effectors of BkdR [6].

In this work, we report the multilayered characterization of the PA2577 protein from $P$. aeruginosa classified to the Lrp/AsnC family. The PA2577 gene was previously identified as up-regulated in $P$. aeruginosa par $A$ and parB mutants, which are characterized by disturbances in chromosome segregation $[23,29,30]$. The loci with an altered expression in par mutants encompass a significant number of genes encoding transcriptional regulators, often with unknown functions [23]. This study aims to decipher the function of one of them.

PA2577 is predicted to encode a DNA-binding transcriptional regulator with the molecular size of $16.5 \mathrm{kDa}$. Its small size as well as domain structure, with the $\mathrm{N}$-terminal 
helix-turn-helix (HTH) motif involved in interactions with DNA and the C-terminal putative ligand-binding domain, are typical for Lrp/AsnC family members [31].

Our results indicate that PA2577 acts locally as a repressor of PA2576 gene coding for a predicted membrane protein with two EamA domains. We show that PA2576 interacts with PA3694 and PA5006, which suggests that the function of this protein could be connected to lipopolysaccharide (LPS) biogenesis. The deletion of PA2577 or PA2576 led to an increased sensitivity of cells to membrane damaging agents, such as EDTA and polymyxin B. Thus, the proper level of these proteins seems to be crucial for the maintenance of membrane functions important for cell adaptation under stress conditions.

\section{Results}

\subsection{Genetic Organization of the P. aeruginosa PA2577 Region and Characteristics of PA2577}

The PA2577 gene of the P. aeruginosa PAO1 reference strain is transcribed in an operon with the PA2578 gene (Figure 1A). PA2577 and PA2578, according to the pseudomonas.com database [32], encode proteins classified as a putative Lrp/AsnC-type transcriptional regulator and a probable acetyltransferase with a GNAT domain, respectively. The divergently transcribed PA2576 gene encodes a membrane protein with two predicted EamA-like domains. Similar to other members of the Lrp/AsnC family, the PA2577 protein consists of two domains: the N-terminally located DNA-binding domain (DBD) with a helix-turn-helix motif (HTH) and the C-terminal putative ligand-binding domain (LBD) (Figure 1A). The HTH motif is predicted to encompass amino acids 1-63 and is the most conserved part among the members of the family as shown in the DBD sequence comparison between PA2577 and seven other Lrp/AsnC-like regulators from P. aeruginosa (Figure 1A). The prediction of the tertiary structure of PA2577 using ColabFold confirmed the two-domain structure of the protein (Figure 1B) [33]. Additionally, the analysis showed high score predictions that L-glutamine could be a possible ligand of PA2577, binding to LBD (Figure 1B). The Swiss-model server [34,35] and HDOCK server [36] were used for the oligo-state assessment and modeling of ligand docking, which resulted in a prediction of PA2577 homo-octamer (Figure 1B). The presented model contained eight molecules of L-glutamine attached to the octamer, one glutamine per one PA2577 monomer. PA2577 LBDs were located in the center of the presented octamer and DBDs outside of it, allowing for DNA binding (Figure 1B).

The bacterial adenylate cyclase two-hybrid (BACTH) system [37] was used to study the dimerization ability of PA2577 in vivo (Figure 1C). The PA2577 was cloned into two pairs of BACTH vectors, derivatives of pairs pUT18C/pKT25 (pLKB4 and pLKB2) and pUT18/pKNT25 (pKGB4 and pKGB5), facilitating the linkage of tested protein with two Bordetella pertussis adenylate cyclase (CyaA) fragments (T18 and T25), either at the N or C-terminus of the protein (Table A1). The reconstruction of adenylate cyclase activity due to the interactions between proteins fused to the CyaA T18/T25 subunits led to the production of CAMP, which bound to the activator CAP and turned on the expression of sugar catabolism genes (e.g., mal or lac operon). The reconstitution of CyaA activity was evaluated by a change in the color of the colonies on the MacConkey plates (red in the case of interacting proteins; data not shown) and by measurements of $\beta$-galactosidase activity in the liquid medium. E. coli BTH101 cyaA cells transformed with pairs of BACTH vectors (one producing PA2577 fused with subunit T25 and the second with T18) showed very strong PA2577-PA2577 interactions (Figure 1C). The highest activity of $\beta$-galactosidase, suggesting the most favorable self-assembly, was detected when the C-ends of proteins were free (T18 and T25 subunits fused with the N-terminal end of PA2577).

Concomitantly, the analysis of the PA2577 oligomerization state using purified PA2577$\mathrm{His}_{6}$ and glutaraldehyde cross-linking confirmed that the purified PA2577 has strong multimerization abilities. Protein dimers as well as higher-order oligomers, possibly octamers, have been observed (Figure 1D). As presented in Figure 1D, results of the crosslinking experiment of PA2577-His 6 complexes migrated slightly slower than predicted, based on the expected molecular weight (MW) of the protein. The PA2577-His 6 dimer has 
molecular weight of about $36 \mathrm{kDa}$, yet on the membrane, the bands around $40 \mathrm{kDa}$ and $45 \mathrm{kDa}$ were detected. Concomitantly, bands above $140-260 \mathrm{kDa}$, which may correspond to predicted octamers or even higher-order complexes, were observed. This could be explained by the differential protein solvation by SDS or the hydrophobicity of the protein. The other aspect is the possible presence of post-translational modification(s) or a potential ligand bound to PA2577 and co-purified with the protein upon cross-linking, which could have influenced the MW of PA2577 and formed higher-order complexes. PA2577 seemed to be very potent to multimerization and apart from the dimeric, tetrameric $(72 \mathrm{kDa}$, hardly visible in the lowest glutaraldehyde concentration tested) or octameric form, it could create intermediate forms likely seen as smear or double/multiple bands on the membrane.

Overall, the presented results indicated that PA2577 created higher-order complexes, which is a common property of other Lrp-like proteins $[16,18,38]$.

A
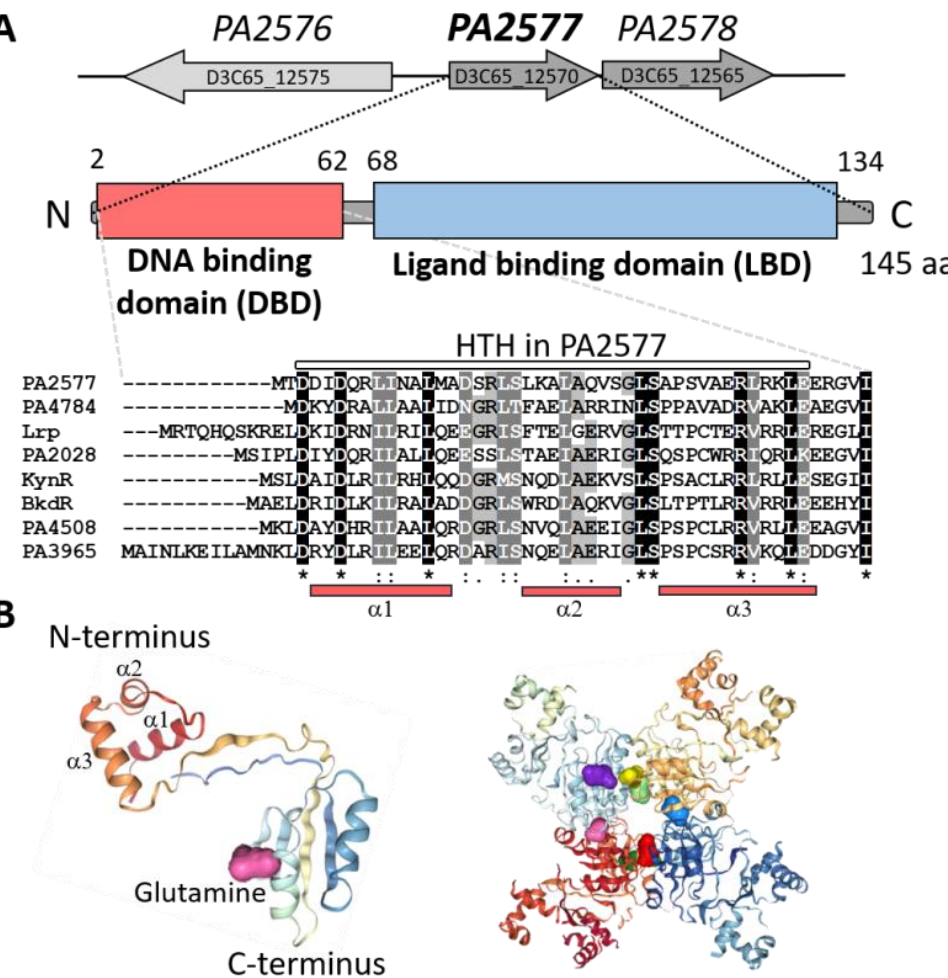

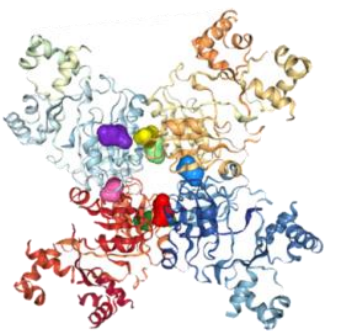

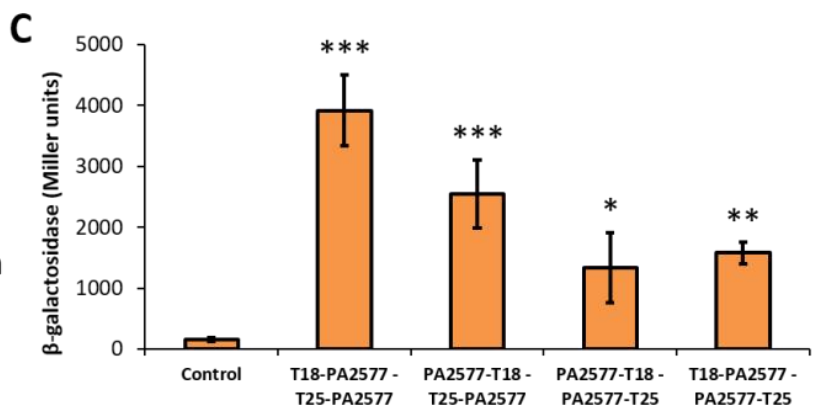

D

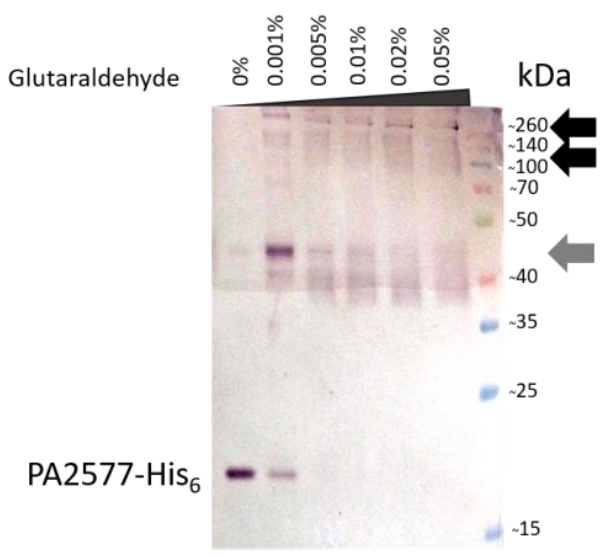

Figure 1. Properties of PA2577 protein from P. aeruginosa. (A) Genomic context of the PA2577 gene in the P. aeruginosa genome and domain structure of PA2577 protein. The gene names from PAO1 and PAO1161 strains are presented (PAO1 above the arrows presenting loci and PAO1161 inside arrows). Alignment represents a comparison of the PA2577 HTH domain with corresponding regions of $7 \mathrm{Lrp} / \mathrm{AsnC}$ proteins from PAO1. Identical residues in all proteins are marked with black. Dots and colons indicate similar residues. Amino acids predicted to be involved in the creation of $\alpha$-helices are underlined (red bars). (B) Predicted structure of PA2577 monomer with marked $\alpha$-helices creating HTH and an octamer with L-glutamine bound as the ligand. (C) BACTH analysis of PA2577 self-interactions. Data represent the mean $\beta$-galactosidase activity \pm SD in cells from three or more cultures of E. coli BTH101 cyaA double transformants. Statistical significance was evaluated by $t$-test ${ }^{*} p$-value $<0.05,{ }^{* *} p$-value $<0.01,{ }^{* * *} p$-value $\left.<0.001\right)$. (D) Oligomerization state of purified PA2577-His 6 assayed by cross-linking with glutaraldehyde. The same amount of purified His $_{6}$-tagged protein was incubated at room temperature for $15 \mathrm{~min}$ with indicated glutaraldehyde concentrations. Samples were separated by SDS-PAGE using $12 \%$ gel and analyzed by Western blot with mouse anti-His 6 antibodies. Dimeric forms and oligomeric complexes are marked by grey and black solid arrows, respectively. 


\subsection{Effect of PA2577 Lack or Excess on Bacterial Growth}

To analyze the role of PA2577 in P. aeruginosa, a PAO1161 $\triangle P A 2577$ strain was constructed and used in several phenotypic analyses (e.g., growth rate in M9 and LB medium, biofilm production analysis and motility abilities); however, no significant differences in comparison with the parental strain could be detected (Figure S1 and data not shown).

To check how the overproduction of PA2577 influenced the bacterial growth, strains carrying pKGB8 (araBADp (EV)) or the pMEB12 vector with PA2577 under the control of the arabinose-induced promoter (araBADp-PA2577 (PA2577+)) were cultured in a medium containing different concentrations of arabinose. This analysis showed a strong negative effect of PA2577 excess on P. aeruginosa growth (Figure 2A). A mild induction of the PA2577 expression by a very low concentration of arabinose $(0.02 \%)$ did not have a significant effect on the kinetics of culture growth, whereas using higher concentrations of arabinose resulted in a more pronounced slowdown of bacterial growth (Figure 2A). Concomitantly, a similar analysis of PA2577 overproduction in E. coli showed no significant differences between EV and PA2577+ cells upon growth in a medium containing various arabinose concentrations (data not shown), indicating that the effect of PA2577 excess on the slowdown of bacterial growth is specific for P. aeruginosa.
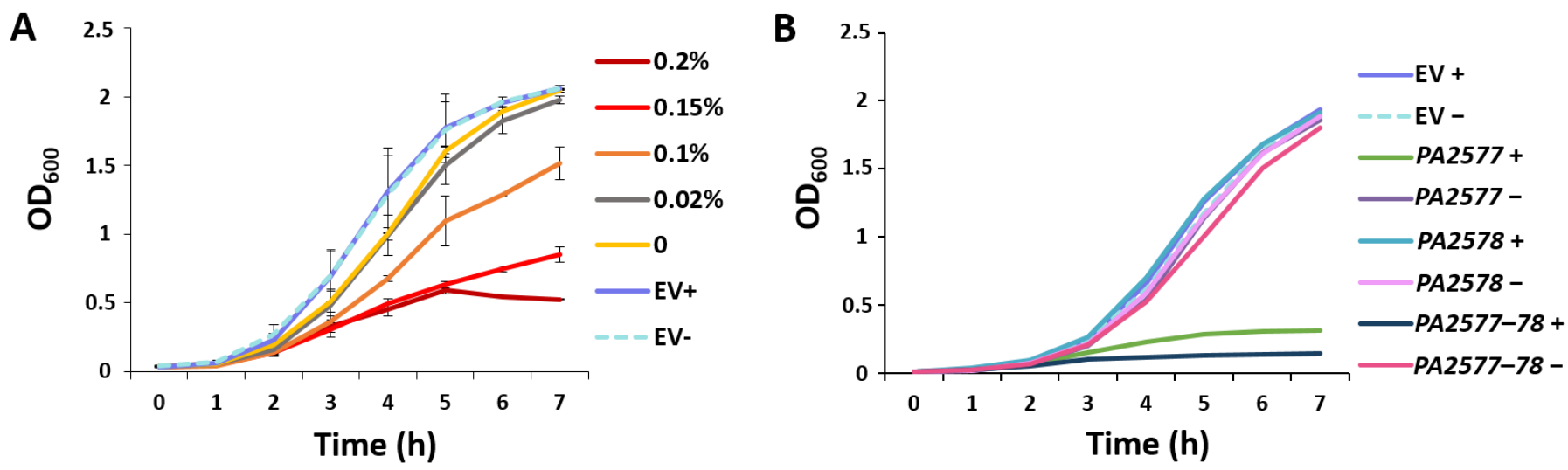

Figure 2. Effect of PA2577 excess on bacterial growth. (A) P. aeruginosa PAO1161 strains carrying empty vector pKGB8 $\operatorname{araBADp}(\mathrm{EV})$ or pMEB12 araBADp-PA2577 grown in LB under selection with the indicated gradient of inducer concentration ( 0 to $0.2 \%$ ). The grey line indicates the growth in the presence of $0.02 \%$ arabinose-conditions selected for RNA-seq analysis. Data represent mean $\mathrm{OD}_{600}$ from three independent replicates $\pm \mathrm{SD}$. (B) Comparison of the impact of PA2577, PA2578

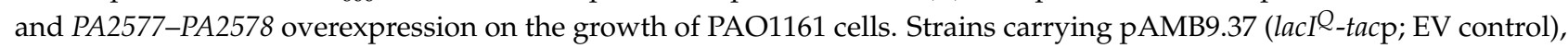
pMEB64 (lacI ${ }^{Q}$-tacp-PA2577), pMEB185 (lacI ${ }^{Q}$-tacp-PA2578) or pMEB186 (lacI ${ }^{Q}$-tacp-PA2577-78) were grown in LB under selection with the addition of $0.5 \mathrm{mM}(+)$ or absence $(-)$ of IPTG. Data represent mean $\mathrm{OD}_{600}$ from three independent replicates, $\mathrm{SD}$ are not shown for clarity.

Additionally, the effect of the PA2577-PA2578 operon (pMEB186; lacI ${ }_{-}-t a c p-P A 2577-$ PA2578 (PA2577-78+)) as well as sole PA2578 (pMEB185; lacI ${ }^{\mathrm{Q}}$-tacp-PA2578 (PA2578+)) overexpression was tested. In conditions when the whole PA2577-PA2578 operon was overexpressed, the negative effect on the growth of cells was even stronger than in the case of the sole PA2577 gene overexpression (Figure 2B). No effect in the case of the PA2578 protein overproduced alone was detected (Figure $2 \mathrm{~B}$ ).

\subsection{Transcriptomic Analysis of P. aeruginosa Cells Overexpressing PA2577}

To identify genes with a changed expression in response to a mild PA2577 overproduction $(0.02 \%$ arabinose, Figure $2 \mathrm{~A})$, an RNA-sequencing (RNA-seq) analysis was performed. Transcriptomes of (PA2577+) cells were compared with those of corresponding cells carrying an empty vector (EV+). Loci specifically altered by a PA2577 excess are listed in Table S1 (fold change (FC) $\leq-1.5$ or $\geq 1.5$; false discovery rate (FDR) adjusted $p$-value 0.01 ). The classification of 171 loci with an altered expression was performed according to PseudoCAP functional categories [32], followed by grouping them into six classes as described 
previously $[23,39]$ (Figure 3A). Additionally, the enrichment of functional categories for differentially expressed genes was performed to point out the most affected functions in response to PA2577. These included phage-related, secretion, chaperones and ncRNA functions. To highlight genes with the highest and the most significant expression alterations, the results of the RNA-seq analysis were visualized as a volcano plot (Figure 3B). Changes in the expression of selected loci (PA0807, PA1698, PA2576 and PA3037) from the list of genes with an altered expression in response to the PA2577 excess were validated using an independent RT-qPCR analysis (Figure 3C). They correlated with RNA-seq data indicating a decreased (PA1698 and PA2576) or increased (PA0807 and PA3037) mRNA level when comparing PA2577+ with EV+ cells.

Slightly more genes with a significantly changed expression had higher mRNA levels (91 loci). Upregulation was observed for 39 genes coding for predicted bacteriophage proteins (Table S1). The most upregulated gene not related to the cryptic phage was the PA0807 encoding AmpDh3 protein (Table S1). This protein is one of three AmpD homologs (PA4522, PA5485 and PA0807) in PAO1 repressing the expression of an ampC beta-lactamase/cephalosporinase gene [40,41]. Upregulation was also observed for all three genes from the PA3035-PA3037 operon, which is putatively involved in the metabolism of glutathione (Table S1).

Among 80 genes downregulated in response to the PA2577 excess, 25 coded for tRNAs of different amino acids (Ala, Gly, Glu, Thr, Phe, Ser, Arg, Asp, Pro, Leu, Trp, Ile, Tyr and Cys). The PA5160.1 tRNA gene was the most downregulated locus $(\mathrm{FC}=0.2)$. Among repressed genes, two significantly downregulated loci attracted special attention-PA2664 and PA2576 (FC $=0.24$ and $\mathrm{FC}=0.26$, respectively). PA2664 encodes flavohemoprotein engaged in the oxidation-reduction process. Flavohemoglobins are poorly understood, but flavoHB from E. coli is involved in the repair of the lipid membrane caused by oxidative/nitrosative stress [42]. The downregulated PA2576 gene is also connected with membrane functions. It is oriented divergently to the PA2577 gene (Figure $1 \mathrm{~A}$ ) and encodes a probable integral inner membrane protein classified as a drug/metabolite transporter based on the existence of two EamA-like domains in its structure. Because of its genomic location in the neighborhood of PA2577, the PA2576 gene was suspected to be the direct target of the PA2577 regulator.

\subsection{Identification of PA2577 Binding Sites in P. aeruginosa Genome}

To check if PA2576 is indeed the direct target of PA2577 and identify other potential PA2577 binding sites in the P. aeruginosa genome, a ChIP-seq analysis was performed. P. aeruginosa $\triangle P A 2577$ cells carrying pMEB84 (lacI ${ }^{Q}$-tacp-PA2577-flag) were grown under

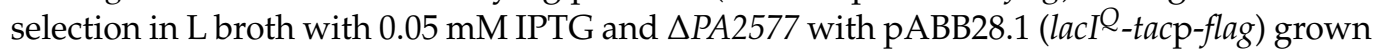
under the same conditions being used as a negative control.

The sequencing of DNA immunoprecipitated using anti-flag antibodies confronted with a negative control revealed as much as 812 binding sites of PA2577. The vast majority of sites was characterized by a very low enrichment and a 2.5 -fold enrichment was chosen as a cut-off value, eliminating about $97 \%$ of peaks (Figure S2A). Such filtering resulted in 25 peaks considered as specific PA2577 binding sites (Table S2). A total of 23 of these peaks was located between 2 and $5.5 \mathrm{Mb}$ of the genome (Figure S2B). The regions of enrichment had an average length of $52336 \mathrm{bp}$ and the median of $13340 \mathrm{bp}$, which showed a very low specificity and broad PA2577 interactions with DNA. Due to the broad peaks and different localization of genes with a changed expression (identified in RNA-seq) relative to the peak summits, no specific motif recognized by PA2577 could be identified. In Table S1, RNA-seq data are presented in the first column marked by the number of PA2577 peaks identified in the ChIP-seq analysis if the gene with a changed expression was localized in the region detected as interacting with PA2577. The 81 genes with a changed expression in response to PA2577 were localized in the regions identified as bound by PA2577.

Only four of obtained peaks had sharp shapes with a clear summit and they encompassed regions between PA0600 and PA0641 (peak 1), PA0980 and PA0975 (peak 14), PA4334 
and PA4342 (peak 18) and PA2581 and PA2573 (peak 25) genes from the PAO1 genome (Table S2, Figure S2C).

Peak no. 1 was 37545 bp long and encompassed the region encoding more than 40 genes (PA0600-PA0641), with the summit of the peak identified in the PA0633 gene encoding a hypothetical protein related to phage functions, such as other genes from the cluster. The induction of the expression of most of the genes from the PA0612-PA0648 cluster was detected in the RNA-seq analysis in response to a mild PA2577 excess (Table S1). Among these genes were the $\operatorname{prtN}$ (PA0610) and ptrB (PA0612) encoding transcriptional regulators involved in stress response. Peak no. 14 was $3241 \mathrm{bp}$ long and was the shortest one among 25 peaks identified for PA2577. In this region, the PA0980-PA0975 genes were located with the $P A 0978$ encoding conserved hypothetical protein with a putative HTH-like and integrase/transposase catalytic domain, in which the peak summit was detected. However, no changes in gene expression in this region were observed under tested conditions in the performed RNA-seq analysis. Peak no. 18 was 7398 bp long and encompassed the PA4334-PA4342 genes, with a summit identified in the PA4336 gene. No changes in gene expression in this region were also observed.

For three PA2577 peaks, the summits were located in intergenic regions (peak 3, 17 and 25) with the highest fold enrichment detected for peak no. 25 encompassing the PA2576/PA2577 promoter region (Table S2). For peak no. 17, the summit was identified in the intergenic region of the PA0715/PA0714 genes and a slight down-regulation was observed for the PA0715 gene encoding a putative RNA-dependent DNA polymerase in response to PA2577 in the RNA-seq analysis (Table S1). Peak no. 3 encompassed the region encoding PA3061-PA3031 (Table S2). The summit of the peak was detected in the intergenic region of the $P A 3035 / P A 3034$ genes. A significant up-regulation of the PA3035PA3037 operon was observed in the performed RNA-seq analysis (Table S1). However, an electrophoretic mobility shift assay (EMSA) with the promoter region of PA3035 showed no clear PA2577 binding to this sequence under tested conditions (data not shown).

Peak 25 comprised the PA2576/PA2577 intergenic region (Figure 4A). The summit of this peak was located between the predicted -10 and -35 regions of the PA2576 promoter close to the predicted PA2577 transcription start site (Figure 4B). To check the ability of the protein to interact with the PA2576/PA2577 intergenic region, an EMSA using purified PA2577-His 6 and a DNA fragment encompassing the sequence was conducted. The data indicate that PA2577 recognized and bound to the PA2576/PA2577 intergenic region as it formed a DNA-protein complex, shifting the fragment in the gel (Figure 4C). Such interactions did not occur for PA2577 incubated with the control DNA fragment.

\subsection{Regulatory Properties of PA2577}

To further evaluate the regulatory properties of PA2577, the PA2577p and PA2576p promoter regions were cloned upstream of a promoter-less $x y l E$ gene in pPTOI. The PA2576p$x y l E$ fusion was active in the heterologous host $E$. coli DH5 $\alpha$, whereas no activity was observed for PA2577p-xylE (Figure 4D and data not shown). The increased expression of PA2577 in cells carrying plasmids with PA2576p-xylE resulted in significantly reduced XylE activity in the cell extracts (Figure 4D), indicating that PA2577 acted as a repressor. In accordance with this observation, the RT-qPCR analysis of the PA2576 transcript level in PA2577-deficient cells showed an increased expression of this gene relative to WT cells grown in rich (LB) or in minimal medium (M9) (Figure 4E). 

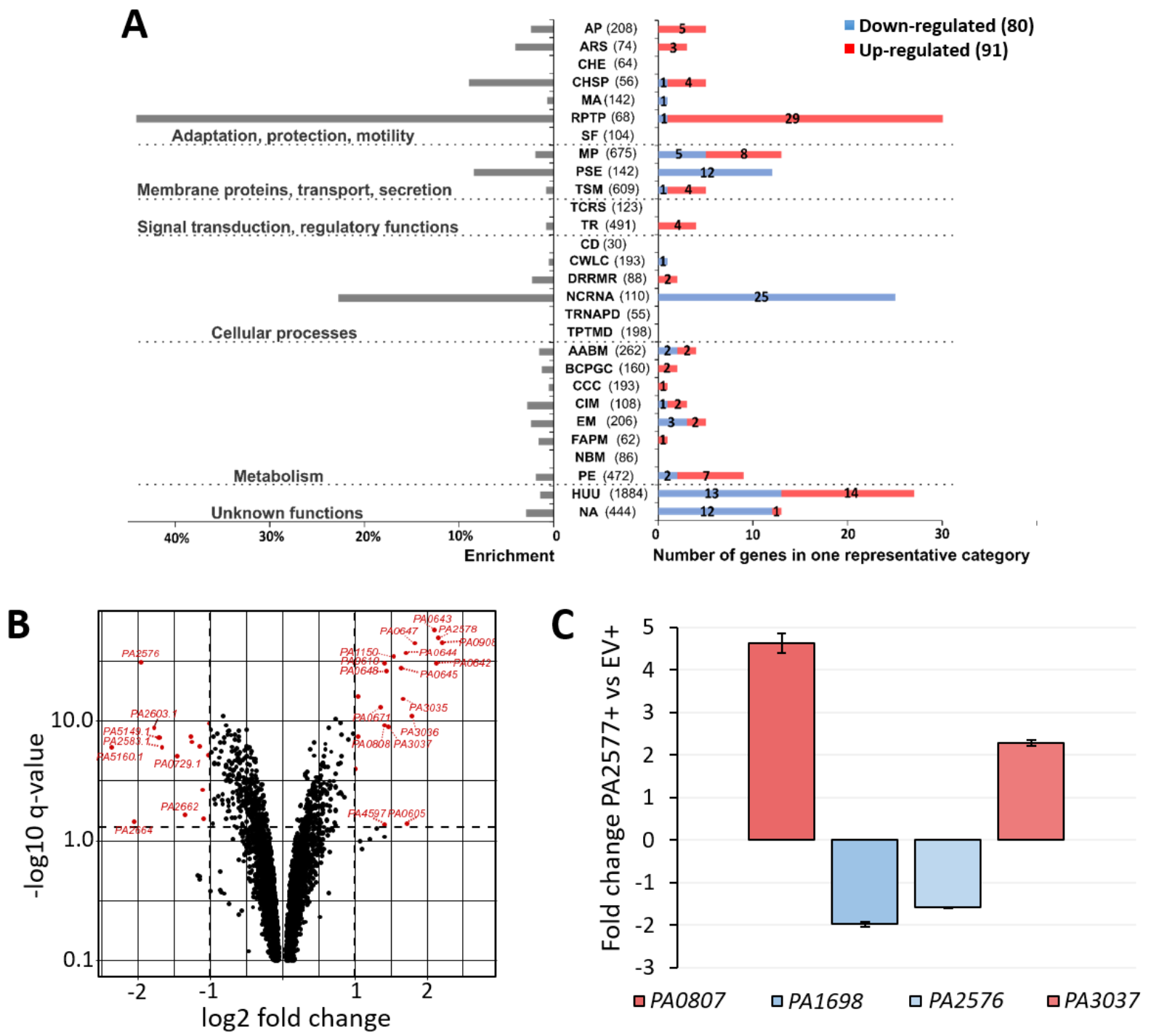

Figure 3. Identification of P. aeruginosa genes affected by PA2577. (A) Comparative transcriptome analysis was performed for PA2577 overproducing cells (PA2577+) vs. EV+ P. aeruginosa PAO1161 cells. Enrichment of PseudoCAP functional categories [32] for 171 genes showing changes in mRNA level in response to mild PA2577 abundance (FC $\leq-1.5$ or $\geq 1.5$, FDR adjusted $p$-value $\leq 0.01$ ). The numbers in brackets show the number of all genes in the PAO1 genome in the indicated PseudoCAP category. One gene could be classified into more than one category and one of the most informative categories was selected (bolded in Table S1). Numbers in red or blue bars denote the number of up- or down-regulated genes, respectively, in each category. The PseudoCAP categories were grouped into six classes as described previously [23,39]. $\mathrm{AP}$-adaptation, protection; ARS—antibiotic resistance and susceptibility; $\mathrm{CHE}$-chemotaxis; $\mathrm{CHSP}$ - chaperones and heat shock proteins; MA—motility and attachment; RPTP—related to phage, transposon, plasmids; SF—secreted factors; MP— membrane proteins; PSE—-protein secretion/export apparatus; TSM-transport of small molecules; TCRS-two-component regulatory systems; TR—-transcriptional regulators; CD—cell division; CWLC—cell wall/LPS/capsule; DRRMR—DNA replication, recombination, modification and repair; NCRNA—non-coding RNA genes; TRNAPD—transcription, RNA processing and degradation; TPTMD—translation, post-translational modification, degradation; AABM-amino acid biosynthesis and metabolism; BCPGC—-biosynthesis of cofactors, prosthetic groups and carriers; CCC—carbon compound catabolism; CIM—central intermediary metabolism; EM—energy metabolism; FAPM—fatty acid and phospholipid metabolism; NBM-nucleotide biosynthesis and metabolism; PE—putative enzymes; HUU—hypothetical, unclassified, unknown; NA—not annotated. (B) Volcano plot visualization of differential expression analysis between transcriptomes of PA2577+ vs. EV+ cells. Each point in the volcano plot represents one gene and the dashed lines represent the cut-off values used. The red dots represent the most significant changes. (C) Validation of RNA-seq data by RT-qPCR analysis. The RT-qPCR was performed using RNA samples obtained for the same conditions as samples used for RNA-seq analysis. Data represent mean fold change for three biological replicates vs. mean expression in WT cells. 
Moreover, the expression of $P A 2577$ and PA2576 was examined at the early $\left(\mathrm{OD}_{600} \sim 0.6\right)$ and late exponential $\left(\mathrm{OD}_{600} \sim 1.5\right)$ phases of growth of P. aeruginosa WT cultures. Results of the RT-qPCR analysis revealed that PA2577 expression was about five times higher in cells collected from the late exponential phase, whereas the PA2576 gene was expressed at a very low level independently of the phase of growth (about 10 times lower in comparison with PA2577) (Figure 4F). Such a low expression level of PA2576 may suggest that this gene was under strict control involving its local regulator and/or possibly also other proteins. A low increase in the PA2576 expression was noticed in the late exponential phase even though the PA2577 was expressed at a higher level. This could be explained by the presence of putative ligand/co-factor, which limited/inhibited the action of PA2577 as the repressor or additional cellular factors, which counteracted the action of PA2577 and were involved in the activation of the $P A 2576$ expression.
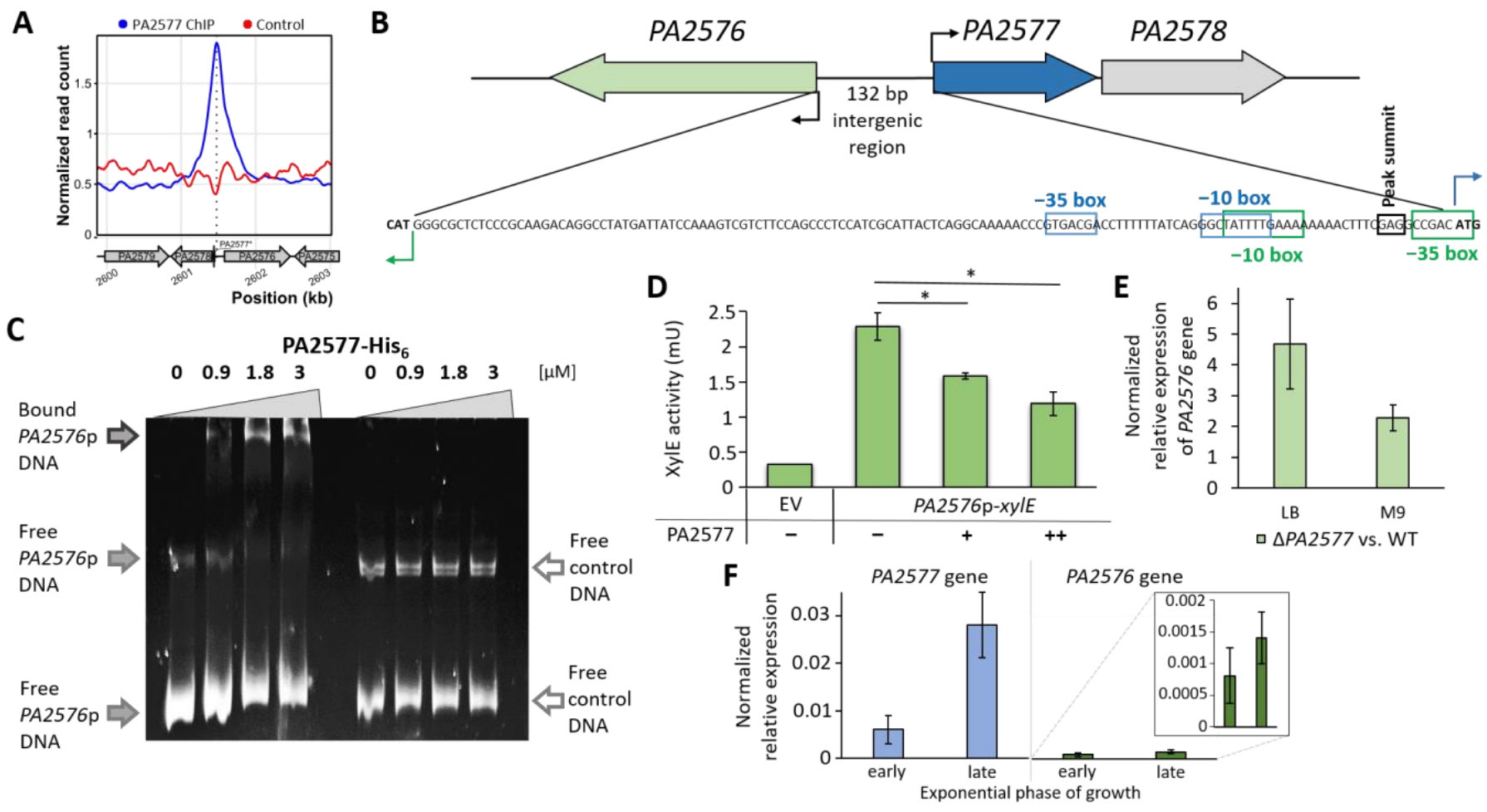

Figure 4. PA2577 interaction with DNA assayed in vivo and in vitro and its regulatory properties. (A) ChIP-seq signal over region encompassing PA2577 binding site in PA2576/PA2577 divergent promoter. The plot shows normalized coverage with reads for indicated positions in PAO1161 $\triangle P A 2577$ genome averaged for ChIP replicates. Genes are presented as grey arrows, only names of PAO1 orthologs are shown for clarity. (B) Schematic picture of PA2577, PA2576 and PA2578 loci with the PA2576/PA2577 intergenic region; -35 and -10 regions of PA2576p and PA2577p predicted using BPROM [43] are marked as well as the summit of ChIP-seq peak. (C) EMSA using PA2577-His 6 and DNA of the PA2576 promoter region; 100 ng of DNA was incubated with an increasing amount of PA2577-His 6 . Samples were separated on a 10\% polyacrylamide gel; $331 \mathrm{bp}$ pCM132 fragment was used as a control to rule out non-specific DNA binding. (D) XylE activity in E. coli DH5 $\alpha$ cells carrying pMEB189 (PA2576p-xylE) containing pMEB64 (tacp-PA2577) vector allowing PA2577 overproduction (+) or control pAMB9.37 (-). Strains were grown under selection in L broth. Data for cells with the promoter-less pPTOI (-xylE) and pAMB9.37 are shown as a background control (EV). Data represent mean $\pm \mathrm{SD}$ from three biological replicates. ${ }^{*}$ indicates $p$-value $<0.05$ in Student's two-tailed $t$-test. (E) Fold change of PA2576 expression in $\triangle P A 2577$ vs. WT cells grown in rich (LB) and minimal (M9) medium and harvested at $\mathrm{OD}_{600} \sim 0.5$. (F) Expression of PA2577 and PA2576 genes in PAO1161 in a rich medium at early $\left(\mathrm{OD}_{600} \sim 0.5\right)$ and late exponential phase of growth $\left(\mathrm{OD}_{600} \sim 1.5\right)$. Data represent mean $\pm \mathrm{SD}$ from three biological replicates. 


\subsection{Characterization of PA2577 Target Gene PA2576}

The $P A 2576$ gene encodes the protein predicted to be localized in the inner membrane and possesses two EamA-like domains, each containing five transmembrane helices. To determine the function of the PA2576 protein, a PAO1161 mutant lacking the PA2576 gene was constructed. Akin to $\triangle P A 2577$ strains, no phenotype changes were observed for the $\triangle P A 2576$ mutant in standard tests (Figure S1). Due to the strong inhibitory effect on $P$. aeruginosa growth caused by the PA2577 overproduction (Figure 2), the influence of PA2576 overexpression was also tested. The growth analysis of PAO1161 carrying

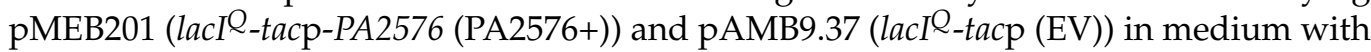
IPTG used as the inducer revealed that the overproduction of PA2576 also strongly inhibited P. aeruginosa growth (Figure S3).

To further characterize PA2577 and PA2576 proteins, a screening for their cellular partners was conducted using a bacterial two-hybrid system as described previously [44,45]. The genomic library [46] constructed in the pUT18C BACTH vector [44] was used together with CyaA T25-PA2576 (pMEB122) and PA2576-CyaA T25 (pMEB121) or CyaA T25-PA2577 (pMEB67) and PA2577-CyaA T25 (pMEB61) used to produce "bait" proteins. Competent BTH101 cells producing "bait" proteins were transformed with the pUT18C library producing "prey" polypeptides, and possible interactants were identified based on CyaA activity reconstitution [45]. Despite the extensive screening of the library, no interactants of PA2577 could be identified with this method.

Concomitantly, the screening for T25-PA2576 interactants revealed two proteins, PA3694 and PA5006. A full-length PA3694 protein was encoded by three independent clones, whereas a $579 \mathrm{bp}$ long part of PA5006 (encoding fragment encompassing 300-493 aa) was identified in one clone. The subsequent cloning of a full-length PA3694 and PA5006 into the BACTH vectors confirmed strong interactions between PA5006 and PA2576 and medium-strength interactions between PA3694 and PA2576 (Figure 5A). The strongest values of $\beta$-galactosidase activity were observed for variants of CyaA T25 fused with the N-terminal end of PA2576 (Figure 5A), which confirmed that the interaction with the C-terminal part of PA2576 was the most preferable way of the interplay. The significance of all interactions was confirmed by control tests of $\beta$-galactosidase activity performed with an empty BACTH vector and appropriate protein fused with a cyaA subunit, where no interactions were observed (Figure S4).

\subsection{Characteristics of PA2577 Network and Its Role in P. aeruginosa}

To better characterize the identified partners of PA2576, the ability of PA3694 and PA5006 to dimerize and to interact with each other was tested. Results of a BACTH assay followed by $\beta$-galactosidase activity testing revealed that both PA3694 and PA5006 were able to dimerize regardless of which fusion $\mathrm{N}$ - or $\mathrm{C}$-terminus of the protein fused with the T18 or T25 CyaA subunit was tested (Figure $5 \mathrm{~B}$ ). What was even more interesting, partners of PA2576 also interacted with themselves (Figure 5B), which suggested the presence of a protein complex consisting of at least three members (PA2576/PA3694/PA5006). For the PA2576 protein, no dimerization was observed (Figure S5).

PA3694 is an uncharacterized small protein probably being a part of an operon of unknown function consisting of six genes (PA3693-PA3698). Based on the amino acid sequence, it is predicted to be a lipoprotein [32].

PA5006 is the first gene from an operon consisting of seven loci (PA5006-PA5012) [47]. $P A 5006$ is the only putative gene in the cluster and probably the same as three other genes (waaP (PA5009), wapP (PA5008) and wapQ (PA5007)) belonging to the operon, encoding LPS kinase, which is responsible for the addition of phosphates to the inner core oligosaccharides of P. aeruginosa LPS (Figure 5). The four kinase genes occur in the cluster together with LPS sugar transferase genes waaF, waaC and wapG (PA5010-PA5012) creating the operon encoding proteins responsible for the construction of the $P$. aeruginosa LPS core, which is built of highly phosphorylated sugars [48,49]. LPS phosphates are necessary for a complete LPS synthesis before its transport to the outer membrane of the cell [47]. 
A
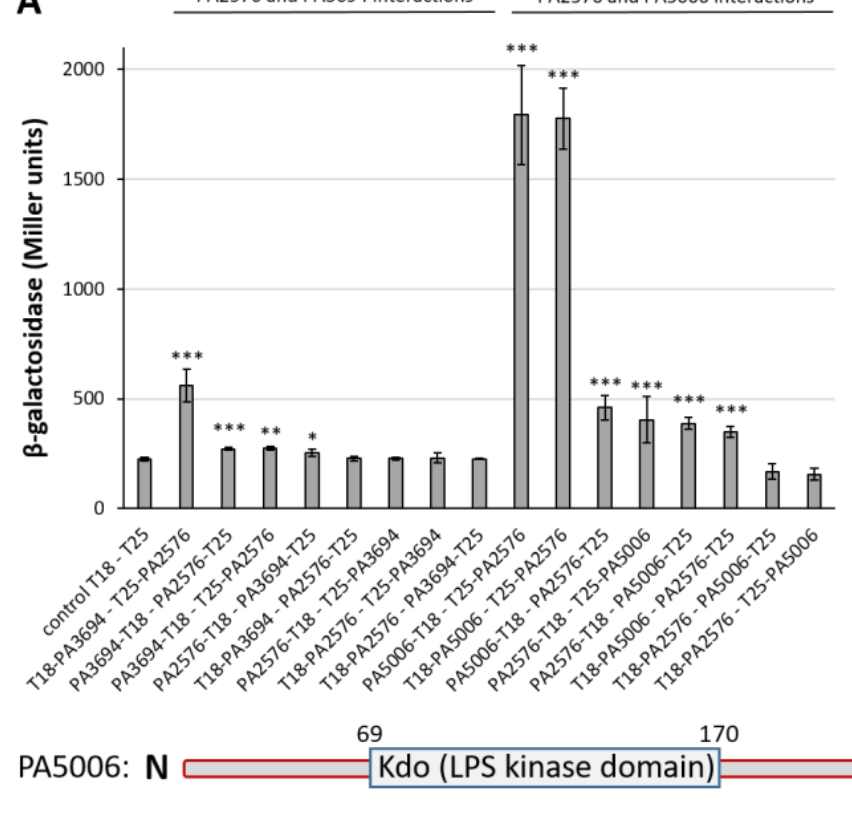

B

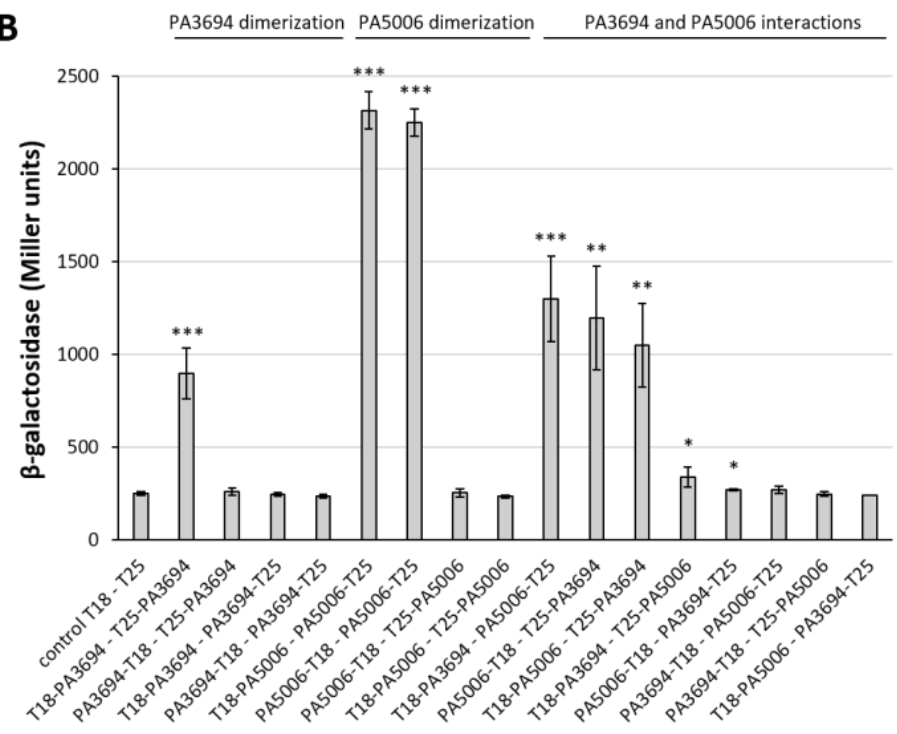

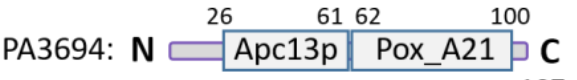

107 aa

Figure 5. BACTH analysis of (A) PA2576 interactions with its two identified partners-PA5006 and PA3694-and (B) PA5006 and PA3694 self-interactions and interactions between each other. Data represent the mean \pm SD values of $\beta$-galactosidase activities from three independent cultures of E. coli BTH101 cyaA ${ }^{-}$double transformants. Statistical significance was evaluated by $t$-test using measurements for transformants carrying double empty vectors as a control $\left({ }^{*} p\right.$-value $<0.05$, ${ }^{* *} p$-value $<0.01,{ }^{* * *} p$-value $<0.001$ ). The schematic domain structure of PA5006 and PA3694 proteins (based on the Kyoto Encyclopedia of Genes and Genomes (KEGG) database) is presented below the charts.

In light of the BACTH results and the existence of an interaction network comprising PA2576/PA3694/PA5006, phenotypic microarrays (BIOLOG) for selected conditions for the $\triangle P A 2576$ and $\triangle P A 2577$ mutants in comparison with the WT strain were performed (plates PM3, PM4, PM5, PM9 and PM13), but no significant differences could be observed in such conditions (data not shown). A phenotype microarrays analysis conducted on plate PM12B indicated an impaired metabolism of the $\triangle P A 2576$ mutant in the presence of polymyxin $B$ under the highest tested concentrations, which suggested disturbances of membrane functions likely connected with LPS synthesis (Figure 6A).

The phenotype was confirmed by a standard growth experiment where PA2576or PA2577-deficient cells grew significantly slower than the WT strain in the minimal M9 medium supplemented with citrate as the carbon source, polymyxin B and EDTA (Figure 6B).

Overall, presented data indicated that PA2577 and PA2576 were involved in the control of membrane functions, which might be perturbed in the presence of agents influencing membrane integrity, e.g., polymyxin B. 


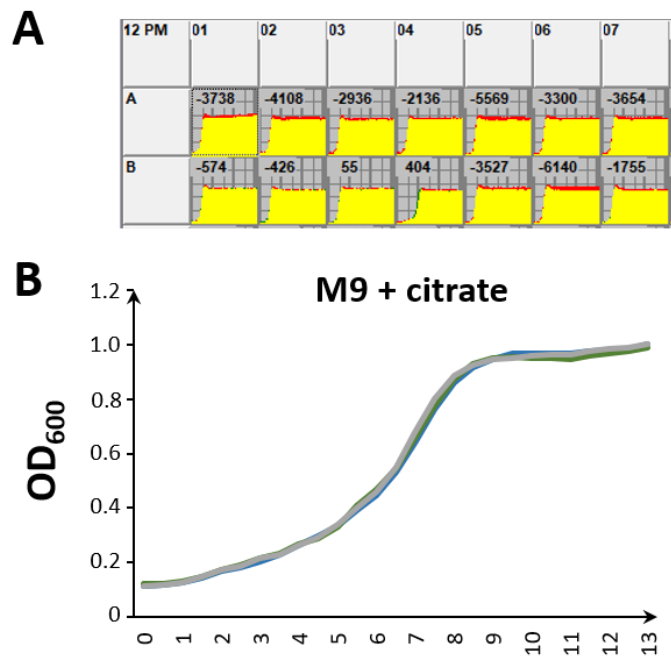

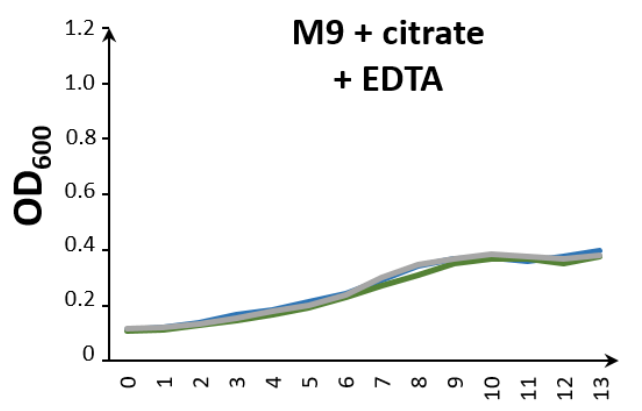

Time (h)
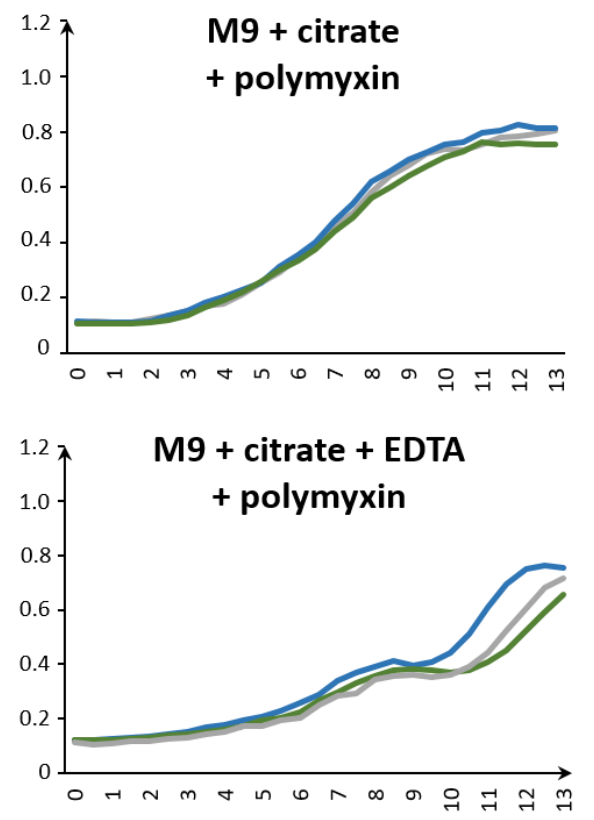

Time (h)

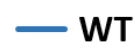

- $\triangle P A 2577$

$\triangle P A 2576$

Figure 6. (A) BIOLOG phenotype microarray results of $\triangle P A 2576$ strain vs. WT strain on plate PM12B. B12 location corresponding to conditions with the highest concentration of polymyxin $B$ is marked. (B) Growth curves of the P. aeruginosa PAO1161 $\triangle P A 2577, \triangle P A 2576$ mutants and WT strain in M9 supplemented with citrate, with the addition of polymyxin B $(1 \mu \mathrm{g} / \mathrm{mL})$ or/and EDTA $(0.5 \mathrm{mM})$ at $37^{\circ} \mathrm{C}$. Data represent mean $\mathrm{OD}_{600}$ from three independent replicates.

\section{Discussion}

In this work, the characterization of the Lrp/AsnC transcriptional regulator PA2577 from $P$. aeruginosa was described. Representatives of the Lrp/AsnC family of regulators appeared to be widely distributed among bacteria and archaea, whereas no Lrp-like TRs were identified in eukaryotic genomes so far [31]. Some prokaryotes encoded only a few (or even none) representatives of the Lrp/AsnC TRs family, e.g., E. coli with three these types of regulators (Lrp, AsnC and $\mathrm{YbaO}$ ), but several bacteria contained dozens of such paralogues [31]. Different compositions of exact families of TRs may be related to the lifestyle, metabolic capabilities and adaptation/survival ability of the bacterial species. The higher number of regulators encoded in the genome often reflects the need to control and coordinate various cellular processes; thus, the complexity of the regulatory and metabolic network allowing adaptation and survival in a changing environment. In the genome of $P$. aeruginosa, known for its high adaptability, nine Lrp/AsnC-type regulators could be identified (PA0515, PA2028, PA2082, PA2246, PA2577, PA3965, PA4508, PA4784 and PA5308).

Our work showed that PA2577 could form multimers, bind DNA and modulate gene expression in P. aeruginosa. An in silico analysis predicted a two-domain structure of PA2577, typical for FFRP, with the N-terminus involved in DNA binding and C-terminal ligand binding domain [31]. The possibility to create octamers was envisioned by the modeling of a PA2577 3D structure based on available 3D structures (Figure 1B). In the 
model, four dimers created an octamer with C-terminal parts of the PA2577 dimers located in the center and DBDs positioned outside of the multimer; thus, allowing interactions with DNA. In the presented model, each PA2577 monomer bound one glutamine; however, the binding of this ligand to PA2577 has not yet been tested experimentally. Studies on the representatives of Lrp/AsnC family members showed that ligand binding may not be necessary to create multimers, such as in Grp from archaeon Sulfolobus tokodaii [50] or DM1 from Pyrococcus sp. OT3 [51]. In fact, ligands were shown to either stabilize the multimer structures as in the case of the DM1 protein or Grp [10,50] or destabilize its integrity similar to how leucine acts on Lrp protein [52].

PA2577 showed a 27\% identity and 49\% similarity with Grp, and conserved amino acids involved in interactions with glutamine in Grp seemed to also be present in PA2577, e.g., S31, Y62, D100, T127 and T129 [50]. In the case of Grp, octamers were formed independent of the ligand, but conformational changes after glutamine binding might have caused the stabilization of the oligomeric structure and modulated protein-DNA interactions [50]. Especially important seemed to be the residues T132 and T134 (T127 and T129 in PA2577), which were highly conserved in most Lrp/AsnC family members. They possibly played a role in the dimer-dimer interface stabilization in the presence of the ligand, which would further reinforce the quaternary structure and possibly exert an effect on the regulatory properties of the protein.

The formation of oligomeric structures by Lrp/AsnC proteins played a pivotal role in their interactions with DNA, sometimes allowing drastic conformation changes of the DNA duplex, such as DNA bending/wrapping [50,53-55], as described for the Lrp dimer [55,56]. DNA bending at a close proximity of the -10 promoter sequence might be involved in transcription control, especially activation [57-59].

The performed RNA-seq analysis showed changes in the expression of 171 genes in response to PA2577. We did not observe a clear correlation of identified PA2577 binding sites in ChIP-seq (using a 2.5-fold enrichment cut-off value) and genes that responded to PA2577 in the RNA-seq analysis under tested conditions, except for PA2576. Under tested conditions, PA2577 acted as the repressor of the PA2576 gene, transcribed divergently to PA2577.

The intergenic region of PA2576/PA2577 genes consisted of tracts of $\mathrm{T}$ and A bases, which may have helped in the modulation of the promoter structure by the bound PA2577 oligomer, possibly octamer, according to the model structure, and possible DNA bending and wrapping similar to LrpC from B. subtilis [53]. The AAAGTTTTTTTTCAAAATA tract encompassed a -10 box of predicted PA2576p as well as PA2577p (Figure 4B). Additionally, $A$ and $T$ tracts between the -10 box and the start codon of PA2576 were present in the PA2576/PA2577 intergenic region, which may also have assisted in the promoter structure modulation after PA2577 binding to exert an effect on gene regulation. Additionally,

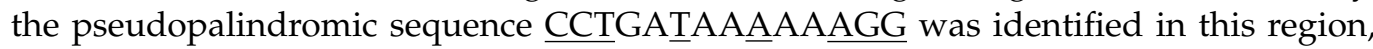
which may have helped in specific recognition by PA2577. The palindromic sequences were preferentially recognized by dimeric forms of regulatory proteins, allowing specific interactions between DNA and protein [60], e.g., the dimer binding consensus sequence for the FL11 from Pyrococcus OT3 was ATAAA ATT TTTAT. Additionally, for many Lrp/AsnC homologs, a few similar homologous sequences with some periodicity (7-8 bp or $18 \mathrm{bp}$ or 30-31 bp) are usually present in the target gene promoters [13]. This may explain the interactions of octamers by facing out DNA binding domains with such arranged DNA sequences and the possibility to wrap DNA around a protein oligomer and the creation of higher-order nucleoprotein complexes.

Based on transcriptomic profiling, PA2577 might be indirectly involved in the control of several genes, e.g., ampDh3 or the PA3035-PA3037 operon. Intriguing was the observed decrease in the tRNA gene expression or upregulation of genes related to phages in response to PA2577 overproduction (Table S1). The mechanism of these changes remains unclear, but we assumed that it could be the cellular response to the stress effect of PA2577 overexpression on bacterial growth (the inhibition of protein synthesis processes), even 
though the concentration of inducer was low. The induction of the expression of the PA0612-PA0648 gene cluster is often observed under different stress-generating growth conditions $[23,39,61]$. Alterations of tRNA gene expression may also account for indirect effects of the PA2577 excess, which was suggested by the results of the ChIP-seq analysis where no binding of PA2577 to the promoters of these loci could be observed.

Genes upregulated in response to PA2577 encompassed the $\operatorname{ptr} B$ encoding protein known as a repressor of the type III secretion system (T3SS) under the stress of DNA damage; hence, the observed effect of the down-regulation of T3SS genes might be an indirect effect of PtrB action [62]. Similarly, the downregulation of the exsE may exert an effect on T3SS genes, as ExsE acts as an anti-anti-activator, which interacts with ExsC, a positive regulator of the type III secretion regulon [63]. Similarly, the upregulation of the PA3035-PA3037 operon, where PA3035 encodes glutathione S-transferase, may be connected with transport functions, since such transferases are engaged in detoxification processes [64].

Our in vitro and in vivo studies showed that PA2577 was directly involved in the regulation of the divergent gene PA2576 encoding a drug-metabolite transporter (DMT) from the EamA family PA2576. The action of PA2577 resembled other local regulators from the Lrp/AsnC family being divergently transcribed in respect to the target gene, e.g., AsnC from E. coli [3,65], BkdR and MdeR from P. putida [6,8], PutR in Agrobacterium tumefaciens [11] or PutR in Rhodobacter capsulatus [5].

The DMT superfamily of proteins comprises 26 families [66]. The EamA family is one of the members of the DMT-like transporters and is named after the O-acetylserine/cysteine export gene from E. coli. In the structure of the representatives of the EamA family, two identical parts comprising individual EamA domains could be distinguished. It is most probably an effect of the intra-protein domain duplication event during evolution [67]. The function of only a few EamA-like representatives is described in the literature, e.g., YdeD from E. coli being an archetype for the family, but also PecM from Erwinia chrysanthemi $[68,69]$. Many family members are involved or predicted to be engaged in the amino acid metabolism, but there is also a branch of nucleotide sugar transporters (NSTs), e.g., the solute carrier family SLC35 [70].

Although we were not able to identify the cargo of the PA2576 transporter, our studies demonstrated its interactions with the putative lipoprotein PA3694 and putative kinase PA5006. These interactions may partially explain the observed disturbances in the growth of the P. aeruginosa $\triangle P A 2576$ mutant in the presence of polymyxin B and EDTA. This was connected with the increased sensitivity of the PA2576 mutant to agents acting on bacterial membranes. This linked the action of PA2576 with the proper maintenance of membrane functions, homeostasis and LPS biosynthesis through PA5006.

Based on the presented results, the model of the regulatory network engaging PA2577, PA2576 and the partners in P. aeruginosa was proposed (Figure 7). PA2577 could create multimers and act as the local regulator of the PA2576 gene. It repressed the expression of PA2576, which possibly diminished the PA2576 pool in the cell and led to disorders in transport function and interactions with partner proteins PA3694 and PA5006. PA2576PA5006-PA3694 created a protein complex, possibly next to the inner membrane, and these interactions may influence putative PA5006 kinase/phosphotransferase activity involved in LPS inner core oligosaccharides phosphorylation. LPS inner core phosphates are necessary for a complete LPS biogenesis, its transport to the periplasm via MsbA (PA4997) and further to the outer membrane [47]. MsbA was shown to translocate components of mature LPS to the periplasmic side of the membrane [71]. The MsbA protein is an ABC transporter that is crucial for the transport of the lipid A-core, being synthesized at the cytoplasm close to the inner membrane [71]. A lipid A-core is most probably transported in a phosphorylated form from cytoplasm, where LPS kinases mediate the addition of phosphate groups [47]. PA2576 as an interactant of phosphate kinase PA5006 possibly participates in this poorly understood process of LPS phosphorylation during biosynthesis. LPS plays an important role in the maintenance of the outer membrane integrity and is 
considered as a virulence factor and one of the strongest antigens inducing host immune response during bacterial infection [71].

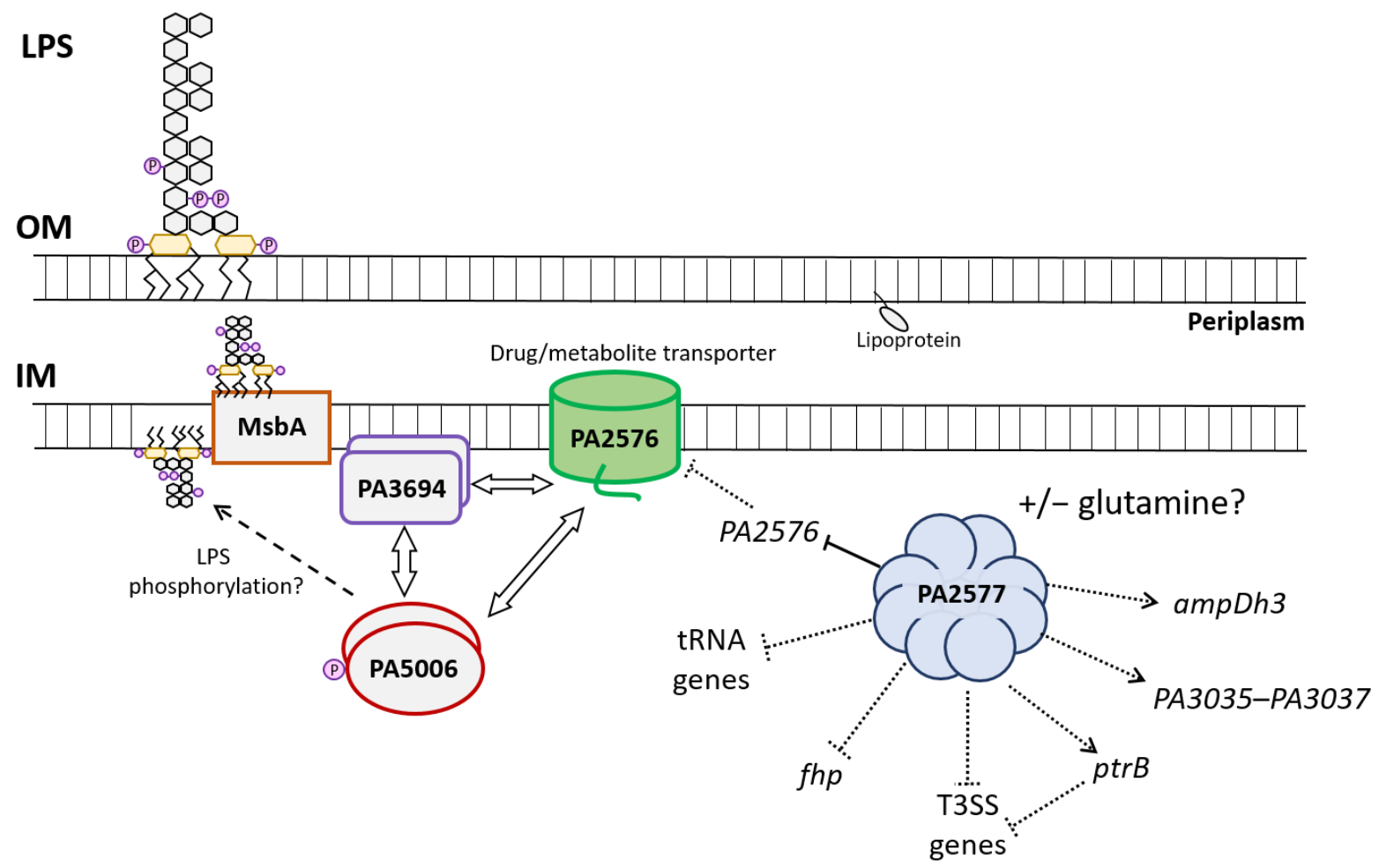

Figure 7. Schematic picture presenting relationships between PA2577 regulator, PA2576 transporter and partners of PA2576 probably existing in dimeric forms in the cytoplasm. PA2577 regulator is presented as an octamer. IM-inner membrane; OM-outer membrane; LPS—lipopolysaccharide. A solid line indicates direct repression by PA2577; dotted lines indicate direct and/or indirect involvement of PA2577 in gene expression control.

As indicated transcriptomic profiling PA2577 might be indirectly involved in the negative regulation of genes encoding a type III secretion system, flavohemoprotein, tRNAs as well as in the activation of the ampDh3 and the PA3035-PA3037 genes (Figure 7). The T3SSs are widely distributed in Gram-negative bacteria and play a pivotal role in pathogen-host interactions during plant, animal or human infections caused by pathogenic bacteria [72]. The T3SS is a key virulence factor composed of a surface-attached needle-like complex that is able to inject cytotoxins directly into host cells, causing cellular damage and, ultimately, death. In P. aeruginosa, the T3SS is expressed by planktonic bacteria during acute infection. Its expression is tightly controlled and induced in response to several environmental signals, including contact with the host cell or low extracellular calcium concentration [73]. Interestingly, it is suggested that structural changes in the LPS of $P$. aeruginosa would affect the ability of bacteria to efficiently secrete cytotoxins and elicit an acute infection. This would be connected with changes in the expression of components of the T3SS; specifically, a less structured LPS lacking the LPS A-band or B-band O antigen would promote cytotoxin production and secretion by bacterium [74]. PA2577 with a possible role in the modulation of LPS synthesis and T3SS expression might be involved in this regulatory cascade. The action of PA2577 could be modulated by the ligand availability, as in the case of other Lrp/AsnC family members [31]. Further investigations have to be performed to unravel the exact mechanism of the PA2577/PA2576/PA5006/PA3694 action. The proposed model (Figure 7) of relationships between PA2577 and its targets points out the directions of future studies and explorations. 


\section{Materials and Methods}

\subsection{Growth Conditions and Bacterial Strains and Plasmids}

Bacterial strains used and constructed in this study are listed in Table A1. Strains were grown in LB or on LB agar at $37^{\circ} \mathrm{C}$. P. aeruginosa strains were also cultivated in M9 minimal medium supplemented with sodium citrate $(0.25 \%)$ as the carbon source and leucine $(10 \mathrm{mM})$ for $l e u^{-}$strains. For plasmid selection in E. coli, media were supplemented with $10 \mu \mathrm{g} / \mathrm{mL}$ chloramphenicol, $50 \mu \mathrm{g} / \mathrm{mL}$ kanamycin or benzyl penicillin at a final concentration of $150 \mu \mathrm{g} / \mathrm{mL}$ in liquid medium or $300 \mu \mathrm{g} / \mathrm{mL}$ in agar plates. For P. aeruginosa strains, the following antibiotics and concentrations were applied: carbenicillin $(300 \mu \mathrm{g} / \mathrm{mL})$, rifampicin $(300 \mu \mathrm{g} / \mathrm{mL})$, kanamycin $(250 \mu \mathrm{g} / \mathrm{mL}$ in a liquid medium; $500 \mu \mathrm{g} / \mathrm{mL}$ in plates) and chloramphenicol ( $75 \mu \mathrm{g} / \mathrm{mL}$ in a liquid medium; $150 \mu \mathrm{g} / \mathrm{mL}$ in plates). For phenotype growth tests, M9 medium supplemented with EDTA in a concentration of $0.5 \mathrm{mM}$ and polymyxin B in a concentration of $1 \mu \mathrm{g} / \mathrm{mL}$ was used.

Competent $E$. coli cells were prepared with the use of the $\mathrm{CaCl}_{2}$ method and transformation was conducted according to a standard procedure [75]. Competent $P$. aeruginosa cells were prepared as described earlier [76].

All plasmids used and constructed in this study are described in Table A1.

Overexpression of selected genes was examined by the transformation of $P$. aeruginosa PAO1161 WT or mutant strain with the pAMB9.37, pABB28.1 or pKGB8 derivatives.

P. aeruginosa PAO1161 $\triangle P A 2577$ and $\triangle P A 2576$ chromosomal mutants were obtained by the method of allele exchange [29]. The donor strain was obtained by transformation of competent E. coli S17-1 cells with pMEB17 or pMEB164 plasmid (derivatives of suicide vector $\mathrm{pAKE600).} \mathrm{P.} \mathrm{aeruginosa} \mathrm{PAO} 1161 \mathrm{Rif}^{\mathrm{R}}$ was used as the recipient. After conjugation, selection and screening of transconjugants were performed by the growth on LB plates with rifampicin and carbenicillin. Removal of the vector was conducted by overnight growth in LB with $10 \%$ sucrose. Selection of colonies with exchanged allele was performed by PCR using primer pairs \#3/\#6 and \#10/\#13 (Table A2).

\subsection{Growth Experiments}

For tests of growth kinetics, liquid media were inoculated with strains propagated on plates. Overnight cultures were diluted 1:100 in a fresh medium and then incubated at $37^{\circ} \mathrm{C}$ whilst shaken. When the experiment was performed in M9 medium, overnight cells grown in LB were washed twice with M9 medium and then used for inoculation. Bacterial growth was monitored by the measurement of optical density at $600 \mathrm{~nm}\left(\mathrm{OD}_{600}\right)$ in a spectrophotometer or with the use of Varioskan Lux Multimode Microplate Reader and SkanIt RE software (Thermo Fisher Scientific, Waltham, MA, USA) in the case of growth in 96-well plates.

\subsection{Analysis of Protein-Protein Interactions in the Bacterial Two-Hybrid System}

The bacterial adenylate cyclase two-hybrid (BACTH) system was used to analyze protein-protein interactions in vivo $[37,44]$. CyaA-T18 and CyaA-T25 fragments were fused to the indicated termini of tested proteins in vectors: pLKB2 and pLKB4 or pKGB4 and pKGB5 (Table A1). Constructs in pLKB plasmids were prepared to obtain $\mathrm{N}$-terminal fusions of cloned genes with $c y a A$ subunits, whereas $\mathrm{pKGB}$ derivatives encoded genes without stop codon fused with $c y a A-\mathrm{T} 18$ and $c y a A-\mathrm{T} 25$ in the C-terminus. Details of cloning design are described in Table A1. Pairs of complementary plasmids were used to co-transform E. coli BTH101 cyaA ${ }^{-}$cells. Double transformants were plated onto MacConkey agar supplemented with $1 \%$ maltose, $0.1 \mathrm{mM}$ IPTG, kanamycin and penicillin, and grown at $30^{\circ} \mathrm{C}$ for $48 \mathrm{~h}$. Randomly picked colonies for each variant of transformation were streaked on a fresh MacConkey plate and again incubated at $30^{\circ} \mathrm{C}$ for $48 \mathrm{~h}$. Clones were used to inoculate liquid cultures in $\mathrm{L}$ broth and after overnight growth in $37^{\circ} \mathrm{C}$, and the $\beta$-galactosidase activity assay was performed in cell extracts as previously described [77]. BACTH system was used in the tests of protein in vivo self/association and for the identification of interactions between two proteins. 


\subsection{Motility and Biofilm Formation Assays}

Motility assays were performed as described previously [78]. To standardize the assays, all plates were prepared with the same volume of the medium. Biofilm amount was measured with the crystal violet staining method in a rich medium [79].

\subsection{RNA Isolation, RNA-Seq and RT-qPCR}

Strains obtained by transformation of PAO1161 with pMEB12 or pKGB8 were used for total RNA preparation. RNA isolation and sequencing as well as data analysis were performed essentially as previously described [79]. Raw data are available in the NCBI's Gene Expression Omnibus (GEO) database (http:/ / www.ncbi.nlm.nih.gov/geo/ (accessed on 30 October 2021)) under accession number GSE186749.

Expression changes for selected genes were confirmed by RT-qPCR using RNA isolated from independent cultures. In total, $1 \mu \mathrm{g}$ of each RNA sample was used for reverse transcription (TranScriba Kit, A\&A Biotechnology, Gdańsk, Poland) with the use of random hexamers. Three technical replicates of PA2577 overproducer and EV control were used. The nadB was used as the reference. RT-qPCR was also used for examination of the expression of PA2577 and PA2576 in the early $\left(\mathrm{OD}_{600} \sim 0.5\right)$ and late exponential $\left(\mathrm{OD}_{600} \sim 1.5\right)$ phases of growth of $P$. aeruginosa WT cultures and for PA2576 also in P. aeruginosa $\triangle P A 2577$ strain. The $r p s L$ gene was used as the reference. Relative gene expression was calculated using the Pfaffl method [80]. All oligonucleotides used in RT-qPCR are listed in Table A2.

\subsection{Chromatin Immunoprecipitation with Sequencing}

ChIP was performed as previously [81,82]. P. aeruginosa $\triangle P A 2577$ strain carrying pMEB12 (araBADp-PA2577-flag) or pKGB8 vectors was grown in a medium containing $0.02 \%$ arabinose as the inducer. Additionally, it was used in the ChIP procedure with antiflag antibodies (MA1-91878, Invitrogen). Data were processed essentially as previously [82]. Sequencing data are available in the NCBI's Gene Expression Omnibus (GEO) database (http://www.ncbi.nlm.nih.gov/geo/ (accessed on 30 October 2021)), under accession number GSE186746.

\subsection{Protein Overproduction and Purification}

To purify His $_{6}$-tagged PA2577 protein, E. coli BL21(DE3) strain was transformed with pMEB105. Cells were grown overnight in LB broth at $37^{\circ} \mathrm{C}$ with $0.5 \mathrm{mM}$ IPTG and then harvested by centrifugation. Phosphate buffer $(50 \mathrm{mM}$ sodium phosphate with $300 \mathrm{mM}$ $\mathrm{NaCl}, \mathrm{pH} 8.0$ ) supplemented with lysozyme at a final concentration of $1 \mathrm{mg} / \mathrm{mL}$ and $1 \mathrm{mM}$ PMSF was used for resuspension of the pellet. The supernatant obtained after sonication and centrifugation was transferred onto Ni-agarose columns (Protino Ni-TED 1000, Macherey-Nagel) and purification of the PA2577-His 6 was carried out according to the manufacturer's instructions. The gradient of imidazole $(20,100,250 \mathrm{mM})$ was used for elution. Purified proteins were dialyzed by overnight incubation in phosphate buffer containing $10 \%(v / v)$ glycerol and stored in small aliquots at $-80{ }^{\circ} \mathrm{C}$. Purification was monitored by SDS-PAGE with a Pharmacia PHAST gel system.

\subsection{Cross-Linking with Glutaraldehyde}

Purified PA2577-His 6 was cross-linked with increasing concentrations of glutaraldehyde as previously described [83]. Samples were then suspended in the loading buffer ( $50 \mathrm{mM}$ Tris $-\mathrm{HCl}(\mathrm{pH}=8.0), 0.1 \mathrm{M} \mathrm{DTT}, 2 \% \mathrm{SDS}, 0.1 \%$ bromophenol blue, $10 \%$ glycerol), boiled for $5 \mathrm{~min}$ and separated on $12 \%(w / v)$ SDS-PAGE gels. After overnight wet transfer onto nitrocellulose membranes (Amersham Protran, Cytiva, Marlborough, MA, USA), Western blot analysis was performed with anti-His 6 mouse antibodies.

\subsection{In Vitro Protein-DNA Interactions}

Electrophoretic mobility shift assay with purified PCR products and PA2577-His 6 was conducted in binding buffer ( $10 \mathrm{mM}$ Tris- $\mathrm{HCl}(\mathrm{pH}=8.5), 10 \mathrm{mM} \mathrm{MgCl}_{2}, 100 \mathrm{mM} \mathrm{KCl}$, 
$0.1 \mathrm{mg} / \mathrm{mL}$ BSA). DNA was amplified with the use of \#16/\#21 primers for PA2576 promoter and \#20/\#21 primers for non-specific DNA. pMEB78 and empty pCM132 were used as templates. DNA was stained by ethidium bromide and visualized by UV light. PA2576p region encompassed the whole 132 bp intergenic fragment between PA2576 and PA2577. The complexes were separated on a $10 \%$ polyacrylamide gel in $0.5 \times$ Tris-borate-EDTA (TBE) buffer.

\subsection{Regulatory Experiments and Promoter Activity Tests}

E. coli $\mathrm{DH} 5 \alpha$ carrying $\mathrm{PPTOI}$ derivatives with a promoter fused to the $x y l E$ reporter gene together with pMEB64 (lacI ${ }^{Q}$-tacp-PA2577) or pAMB9.37 (lacI ${ }^{Q}$-tacp) were assayed for catechol 2,3-oxygenase activity (the product of $x y l E$ gene). The experiment was performed as previously described [84] using cell extracts prepared from exponentially growing cultures in L broth. Measurements of the amount of the protein in extracts were indicated by the Bradford assay [85].

\subsection{Screening for Protein Partners}

For the search and screening of protein interactants, the available PAO1161 genome library constructed in the pUT18C vector (carrying T18 cyaA fragment) was used [46]. Screening of partners was performed based on the previously described procedure using protein-protein interactions in the bacterial two-hybrid system [37,45]. PA2577 and PA2576 genes were cloned in the pLKB2 and pKGB5 plasmids to obtain proteins fused with the T25 cyaA subunit as described in Table A1. Competent BTH101 cells carrying pMEB121 or pMEB122 and pMEB61 or pMEB67 were prepared using the $\mathrm{CaCl}_{2}$ method and used for transformation with pUT18C, containing random fragments of P. aeruginosa genomic DNA. The mixture obtained after the transformation procedure was washed with sterile water to discard the rich medium and, after that, plated onto M9 minimal medium supplemented with kanamycin, penicillin, $75 \mu \mathrm{M}$ thiamine, $1 \%$ maltose, $40 \mu \mathrm{M}$ X-gal and $0.1 \mathrm{mM}$ IPTG. Plates were incubated for 5 days at $30^{\circ} \mathrm{C}$ and all blue colonies indicating the interaction between T18 and T25 cyaA subunits and reconstitution of CyaA activity were re-streaked on the same medium. Plasmid DNA isolated from colonies that remained blue after restreaking was used to perform the transformation of E. coli BTH101 cells carrying empty pLKB2 or pMEB122/pMEB67. The red color of colonies obtained on MacConkey plates for the transformation of cells carrying PA2576 or PA2577 and white colonies in the case of cells with an empty vector were presumed as the confirmation of identified interactant. Plasmid DNA containing a fragment of positively verified putative partners was sequenced. Genes encoding identified partners were then cloned into the BACTH vectors and interactions with full-length proteins were tested.

\subsection{Phenotype Microarrays Analysis}

Phenotypic Microarray Plates (PM3, PM4, PM5, PM9, PM12B and PM13) (Biolog Inc., Hayward, CA, USA) were used to test the growth capacity in different conditions of the analyzed PAO1161 WT, $\triangle P A 2576$ and/or $\triangle P A 2577$ strains as previously described [86,87]. $P$. aeruginosa strains taken from $-80^{\circ} \mathrm{C}$ stocks were grown on L agar plates at $37^{\circ} \mathrm{C}$ and used to prepare inoculation cultures. The analysis was repeated twice for each plate.

Supplementary Materials: The following are available online at https:/ /www.mdpi.com/article/10 $.3390 /$ ijms222413340/s1.

Author Contributions: Conceptualization, A.A.B.; methodology, M.M., A.K. and A.A.B.; formal analysis, M.M., A.K. and A.A.B.; investigation, M.M.; resources, M.M., A.K. and A.A.B.; data curation, M.M., A.K. and A.A.B.; writing-original draft preparation, M.M., A.K. and A.A.B.; writing—review and editing, M.M., A.K. and A.A.B.; visualization, M.M., A.K. and A.A.B.; supervision, A.A.B.; project administration, A.A.B.; funding acquisition, A.A.B. All authors have read and agreed to the published version of the manuscript.

Funding: This research was funded by the National Science Centre in Poland, grant number 2015/18/E/NZ2/00675. 
Institutional Review Board Statement: Not applicable.

Informed Consent Statement: Not applicable.

Data Availability Statement: Raw data of RNA-seq and ChIP-seq are available in the NCBI's Gene Expression Omnibus (GEO) database under accession numbers GSE186749 and GSE186746.

Acknowledgments: We gratefully acknowledge Jan Gawor, Karolina Zuchniewicz and Robert Gromadka (DNA Sequencing and Synthesis Facility, IBB PAS, Warsaw, Poland) for performing DNA sequencing. We thank the Staff of Genomed S.A. (Poland) for performing RNA sequencing. We thank Grazyna Jagura-Burdzy and Magdalena Kusiak (Laboratory of DNA Segregation and Life Cycle of Proteobacteria, IBB PAS, Warsaw, Poland) for the opportunity to use the P. aeruginosa PAO1161 library. We gratefully acknowledge Tamara Aleksandrzak-Piekarczyk (Laboratory of Lactic Acid Bacteria, IBB PAS, Warsaw, Poland) for performing the phenotype microarrays analysis. This work was supported by the National Science Centre in Poland (grant 2015/18/E/NZ2/00675). We also acknowledge financial and technical support from the Institute of Biochemistry and Biophysics, the Polish Academy of Sciences.

Conflicts of Interest: The authors declare no conflict of interest.

\section{Appendix A}

Table A1. Bacterial strains and plasmids used and constructed in this study.

\begin{tabular}{|c|c|c|}
\hline Strain Name & Description & Reference \\
\hline \multicolumn{3}{|l|}{ Escherichia coli } \\
\hline $\mathrm{DH} 5 \alpha$ & $\begin{array}{l}\mathrm{F}-\text { } \text { \$80lacZ } \triangle M 15 \Delta\left(\text { lacZYA-argF) U169 recA1 endA1 hsdR17 }\left(\mathrm{r}_{\mathrm{K}}-, \mathrm{m}_{\mathrm{K}}^{+}\right) \text {phoA supE44 }\right. \\
\lambda \text { thi-1 gyrA96 relA1 }\end{array}$ & [88] \\
\hline S17-1 & pro $\Delta h s d R h s d M^{+} \operatorname{rec} A \mathrm{Tp}^{\mathrm{R}} \mathrm{Sm}^{\mathrm{R}} \Omega \mathrm{RP} 4-\mathrm{Tc}:: \mathrm{Mu} \mathrm{Kn}:: \mathrm{Tn} 7$ & [89] \\
\hline BL21 & $\mathrm{F}-\operatorname{ompT} h s d S_{\mathrm{B}}\left(\mathrm{r}_{\mathrm{B}}{ }^{-} \mathrm{m}_{\mathrm{B}}{ }^{-}\right)$gal dcm $(\lambda \mathrm{DE} 3)$ & Novagen \\
\hline BTH101 & $\mathrm{F}-$ cya-99 araD139 galE15 galK16 rpsL1 (Str $\left.{ }^{\mathrm{R}}\right)$ hsdR2 mcrA1 mcrB1 & [37] \\
\hline \multicolumn{3}{|c|}{ Pseudomonas aeruginosa } \\
\hline PAO1161 & PAO1161 Rif ${ }^{\mathrm{R}}$ leu-, $\mathrm{r}-, \mathrm{m}-$ & [30] \\
\hline PAO1161 & PAO1161 Rif ${ }^{\mathrm{r}-}-\mathrm{m}-$ & {$[90]$} \\
\hline PAO1161 $\triangle P A 2577$ & PAO1161 Rif ${ }^{R}$ with deleted gene PA2577, allele exchange with the use of pMEB17 & This study \\
\hline PAO1161 $\triangle P A 2576$ & PAO1161 Rif ${ }^{\mathrm{R}}$ with deleted gene PA2576, allele exchange with the use of pMEB164 & This study \\
\hline Plasmid Name & Description & Reference \\
\hline pBBR1-MCS-1 & $\mathrm{Cm}^{\mathrm{R}}$, IncA/C broad-host-range cloning vector, lacZ $\alpha-\mathrm{MCS}$, mob, T7p, T3p & [91] \\
\hline pAMB9.37 & pBBR1-MCS-1 derivative with lacI ${ }^{\mathrm{Q}}$-tacp, expression vector & [92] \\
\hline pABB28.1 & pBBR1-MCS-1 derivative with lacI ${ }^{Q}$-tacp-flag, expression vector & {$[82]$} \\
\hline pAKE600 & $\mathrm{Ap}^{\mathrm{R}}$, ori $_{\mathrm{MB} 1}$, ori $_{\mathrm{RK} 2}, \mathrm{sacB}$, suicide vector & [93] \\
\hline pBGS18 & $\mathrm{Km}^{\mathrm{R}}$, ori $\mathrm{MB}_{1}$, cloning vector & [94] \\
\hline pCM132 & $\begin{array}{l}\mathrm{Km}^{\mathrm{R}} \text {, oriC } C_{\mathrm{ColE} 1}, \text { ori } V_{\mathrm{IncP}}, \text { oriT, } \text { traJ', } \operatorname{trf} A \text {, broad-host-range vector, promoter-less lac } \mathrm{Z} \\
\text { reporter gene }\end{array}$ & [95] \\
\hline pET28a $(+)$ & $\mathrm{Km}^{\mathrm{R}}$, ori $\mathrm{MB}_{1}, \mathrm{~T} 7 \mathrm{p}, \mathrm{lacO}, \mathrm{His}_{6}$-tag, $\mathrm{T} 7 \mathrm{tag}$, expression vector & Novagen \\
\hline pPTOI & $\mathrm{Km}^{\mathrm{R}}$, ori $V_{\mathrm{pSC} 101}$, promoter-less $x y l E$ cassette & [96] \\
\hline pET28mod & $\mathrm{Km}^{\mathrm{R}}$, ori $_{\mathrm{MB} 1}, \mathrm{~T} 7 \mathrm{p}, \mathrm{lacO}, \mathrm{His}_{6}$-tag, modified to remove $\mathrm{T} 7 \mathrm{tag}$ & [97] \\
\hline pKAB240 & $\mathrm{Ap}^{\mathrm{R}}$, ori ${ }_{\mathrm{MB} 1}$, pUC19 derivative with $\mathrm{His}_{6}$-mcs (MunI, HindIII, NotI, XhoI, BamHI)-flag & [82] \\
\hline pKGB8 & $\mathrm{Cm}^{\mathrm{R}}$, broad-host-range expression vector, ori ${ }_{\text {IncA } / \mathrm{C}}, \operatorname{araC}$-araBADp & [39] \\
\hline pUT18C & $\mathrm{Ap}^{\mathrm{R}} ;$ ori $_{\mathrm{ColE1}}$, lacp-cyaT18-mcs & [37] \\
\hline pUT18 & $\mathrm{Ap}^{\mathrm{R}} ;$ ori $_{\mathrm{ColE} 1}$, lacp-mcs-cyaT18 & [37] \\
\hline
\end{tabular}


Table A1. Cont.

\begin{tabular}{|c|c|c|}
\hline Plasmid Name & Description & Reference \\
\hline pKT25 & $\mathrm{Km}^{\mathrm{R}}$, ori $\mathrm{p}_{15}$, lacp-cyaT25-mcs & [37] \\
\hline pKNT25 & $\mathrm{Km}^{\mathrm{R}}$; ori ${ }_{\mathrm{p} 15}$, lacp-mcs-cyaT25 & [37] \\
\hline pLKB4 & pUT18C with modified $m c s$ & [98] \\
\hline pKGB4 & pUT18 with modified $m c s$ & [98] \\
\hline pLKB2 & pKT25 with modified $m c s$ & [98] \\
\hline pKGB5 & pKNT25 with modified mcs & [98] \\
\hline pMEB3 & $\begin{array}{l}\text { pET28mod derivative, containing PA2577 gene inserted as EcoRI-SacI fragment } \\
\text { amplified with the use of \#1 and \#2 primers to obtain } \text { His }_{6}-P A 2577 \text { fusion }\end{array}$ & This study \\
\hline pMEB6 & $\begin{array}{l}\text { pAKE600 derivative with upstream region of PA2577 gene inserted as EcoRI-HindIII } \\
\text { fragment amplified with the use of \#3 and \#4 primers }\end{array}$ & This study \\
\hline pMEB11 & $\begin{array}{l}\text { pBGS18 derivative with downstream region of PA2577 gene inserted as } \\
\text { HindIII-BamHI fragment amplified with the use of \#5 and \#6 primers }\end{array}$ & This study \\
\hline pMEB12 & $\begin{array}{l}\text { pKGB8 derivative, containing PA2577 gene under the control of } B A D \text { p promoter; } \\
P A 2577 \text { gene from pMEB3 inserted as EcoRI-SacI fragment }\end{array}$ & This study \\
\hline pMEB17 & $\begin{array}{l}\text { pAKE600 derivative with fused upstream and downstream region of PA2577 gene; } \\
\text { downstream region from pMEB11 inserted into pMEB6 as HindIII-BamHI creating up } \\
\text { and down fusion linked with HindIII }\end{array}$ & This study \\
\hline pMEB58 & $\begin{array}{l}\text { pKGB4 derivative containing PA2577 gene without stop codon fused with T18; PA2577 } \\
\text { amplified with the use of primers \#1 and \#18 inserted as EcoRI-KpnI fragment }\end{array}$ & This study \\
\hline pMEB61 & $\begin{array}{l}\text { pKGB5 derivative containing PA2577 gene without stop codon fused with T25; PA2577 } \\
\text { amplified with the use of primers \#1 and \#18 inserted as EcoRI-KpnI fragment }\end{array}$ & This study \\
\hline pMEB64 & $\begin{array}{l}\text { pAMB9.37 derivative with inserted EcoRI-XhoI fragment containing PA2577 gene } \\
\text { (cloned from pMEB3) under control of tacp promoter }\end{array}$ & This study \\
\hline pMEB67 & $\begin{array}{l}\text { pLKB2 derivative encoding T25-PA2577 translational fusion; PA2577 gene from } \\
\text { pMEB64 inserted as EcoRI-KpnI fragment }\end{array}$ & This study \\
\hline pMEB69 & $\begin{array}{l}\text { pLKB4 derivative encoding T18-PA2577 translational fusion; PA2577 gene from } \\
\text { pMEB64 inserted as EcoRI-KpnI fragment }\end{array}$ & This study \\
\hline pMEB78 & $\begin{array}{l}\text { pCM132 derivative with } 192 \text { bps fragment containing intergenic region upstream of } \\
P A 2576 \text { amplified with the use of \#16 and \#17 primers fused with lacZ to obtain } \\
\text { transcriptional fusion }\end{array}$ & This study \\
\hline pMEB79 & $\begin{array}{l}\text { pKAB240 derivative with PA2577 gene fused with flag-tag; PA2577 gene without stop } \\
\text { codon amplified with the use of } \# 1 \text { and \#7 primers inserted as EcoRI-XhoI fragment }\end{array}$ & This study \\
\hline pMEB83 & $\begin{array}{l}\text { pAMB9.37 with modified mcs (EcoRI-PstI-SmaI-BglII-SalI inserted in the place of } \\
\text { EcoRI-XhoI fragment) }\end{array}$ & This study \\
\hline pMEB84 & $\begin{array}{l}\text { pMEB83 with inserted EcoRI-SmaI fragment from pMEB79 containing PA2577-flag } \\
\text { fusion }\end{array}$ & This study \\
\hline pMEB105 & $\begin{array}{l}\text { pET28mod derivative, containing PA2577 gene inserted as NcoI-XhoI fragment } \\
\text { amplified with the use of \#8 and \#9 primers to obtain } P A 2577-\mathrm{His}_{6} \text { fusion }\end{array}$ & This study \\
\hline pMEB121 & $\begin{array}{l}\text { pKGB5 derivative containing PA2576 gene without stop codon fused with T25; PA2576 } \\
\text { amplified with the use of primers \#19 and \#24 inserted as EcoRI-BamHI fragment }\end{array}$ & This study \\
\hline pMEB122 & $\begin{array}{l}\text { pLKB2 derivative encoding T25-PA2576 translational fusion; PA2576 gene inserted as } \\
\text { EcoRI-BamHI fragment }\end{array}$ & This study \\
\hline pMEB156 & $\begin{array}{l}\text { pAKE600 derivative with upstream region of PA2576 gene inserted as EcoRI-HindIII } \\
\text { fragment amplified with the use of } \# 10 \text { and } \# 11 \text { primers }\end{array}$ & This study \\
\hline pMEB157 & $\begin{array}{l}\text { pBGS18 derivative with downstream region of } P A 2576 \text { gene inserted as } \\
\text { HindIII-BamHI fragment amplified with the use of } \# 12 \text { and } \# 13 \text { primers }\end{array}$ & This study \\
\hline
\end{tabular}


Table A1. Cont.

\begin{tabular}{|c|c|c|}
\hline Plasmid Name & Description & Reference \\
\hline pMEB164 & $\begin{array}{l}\text { pAKE600 derivative with fused upstream and downstream region of PA2576 gene; } \\
\text { downstream region from pMEB157 inserted into pMEB156 as HindIII-BamHI creating } \\
\text { up and down fusion linked with HindIII }\end{array}$ & This study \\
\hline pMEB185 & $\begin{array}{l}\text { pAMB9.37 derivative with inserted EcoRI-KpnI fragment containing PA2578 gene } \\
\text { amplified with the use of \#25 and \#26 under control of tacp promoter }\end{array}$ & This study \\
\hline pMEB186 & $\begin{array}{l}\text { pAMB9.37 derivative with inserted EcoRI-KpnI fragment containing PA2577-PA2578 } \\
\text { operon amplified with the use of \#1 and \#26 under control of tacp promoter }\end{array}$ & This study \\
\hline pMEB189 & $\begin{array}{l}\text { pPTOI derivative with } 192 \text { bps fragment containing intergenic region upstream of } \\
\text { PA2576 amplified with the use of \#16 and \#17 primers fused with } x y l E \text { to obtain } \\
\text { transcriptional fusion }\end{array}$ & This study \\
\hline pMEB201 & $\begin{array}{l}\text { pAMB9.37 derivative with inserted EcoRI-XhoI fragment containing PA2576 gene } \\
\text { amplified with the use of \#19 and \#22 primers under control of tacp promoter }\end{array}$ & This study \\
\hline pMEB239 & $\begin{array}{l}\text { pLKB4 derivative encoding T18-PA3694 translational fusion; PA3694 gene inserted as } \\
\text { EcoRI-SacI fragment }\end{array}$ & This study \\
\hline pMEB240 & $\begin{array}{l}\text { pLKB4 derivative encoding T18-PA5006 translational fusion; PA5006 gene inserted as } \\
\text { BamHI-SacI fragment }\end{array}$ & This study \\
\hline pMEB242 & $\begin{array}{l}\text { pLKB2 derivative encoding T25-PA5006 translational fusion; PA5006 gene inserted as } \\
\text { BamHI-SacI fragment }\end{array}$ & This study \\
\hline pMEB246 & $\begin{array}{l}\text { pKGB4 derivative containing PA5006 gene without stop codon fused with T18; PA5006 } \\
\text { amplified with the use of primers \#29 and \#31 inserted as BamHI-SacI fragment }\end{array}$ & This study \\
\hline pMEB247 & $\begin{array}{l}\text { pKGB5 derivative containing PA5006 gene without stop codon fused with T25; PA5006 } \\
\text { amplified with the use of primers \#29 and \#31 inserted as BamHI-SacI fragment }\end{array}$ & This study \\
\hline pMEB248 & $\begin{array}{l}\text { pKGB5 derivative containing PA3694 gene without stop codon fused with T25; PA3694 } \\
\text { amplified with the use of primers \#27 and \#32 inserted as EcoRI-SacI fragment }\end{array}$ & This study \\
\hline pMEB249 & $\begin{array}{l}\text { pKGB4 derivative containing PA3694 gene without stop codon fused with T18; PA3694 } \\
\text { amplified with the use of primers \#27 and \#32 inserted as EcoRI-SacI fragment }\end{array}$ & This study \\
\hline pMEB250 & $\begin{array}{l}\text { pLKB2 derivative encoding T25-PA3694 translational fusion; PA3694 gene inserted as } \\
\text { EcoRI-SacI fragment }\end{array}$ & This study \\
\hline
\end{tabular}

Table A2. List of primers used in this study.

\section{Primers Used to Amplify DNA Fragments for Cloning}

\begin{tabular}{|c|c|c|}
\hline No. & Name & Sequence $5^{\prime}-3^{\prime}$ \\
\hline$\# 1$ & 2577ESF & GC GAATTC ATGACCGATGACATCGACC \\
\hline \#2 & 2577ESR & GC GAGCTC GAACCAGCGTTGCAGGATTG \\
\hline$\# 3$ & 2577EHuF & GC GAATTC CCGAATACGCAGCGCCAGAAC \\
\hline$\# 4$ & 2577EHuR & GC AAGCTT TCATCAATCGGTCATGTCGGCCTCG \\
\hline \#5 & $2577 \mathrm{HBdF}$ & GC AAGCTT TGAGCGAGGCACTCCGCATGC \\
\hline$\# 6$ & 2577HBdR & GC GGATCC GCCGTTGCGGCGGTCGAACAG \\
\hline \#7 & 2577EX & CG CTCGAG GGTCATCGGGGGGAGCCG \\
\hline$\# 8$ & $2577 \mathrm{NXF}$ & GC CCATGG ATGACCGATGACATCGACC \\
\hline$\# 9$ & 2577NXR & CG CTCGAG ACCGGAACCGGATCCGGTCATCGGGGGGAGCCG \\
\hline$\# 10$ & $2576 \mathrm{EHuF}$ & GC GAATTC CGTTCTTCCAGCTTGCGCAG \\
\hline$\# 11$ & 2576EHuR & GCC AAGCTT TCA ATCGTT CAT GGGCGCTCTC \\
\hline$\# 12$ & $2576 \mathrm{HBdF}$ & GCC AAGCTT TGA GGCGCGGGGGAAAGAAAAAG \\
\hline$\# 13$ & $2576 \mathrm{HBdR}$ & GC GGATCC GTACTGTTCTTCGAAGACCAG \\
\hline
\end{tabular}


Table A2. Cont.

\begin{tabular}{|c|c|c|}
\hline \multicolumn{3}{|c|}{ Primers Used to Amplify DNA Fragments for Cloning } \\
\hline No. & Name & Sequence $5^{\prime}-3^{\prime}$ \\
\hline$\# 14$ & p2577EBF & GC GAATTC GCATGC CCAGCGCGGCACAGGCG \\
\hline$\# 15$ & p2577EBR & GC GGATCC CATGTCGGCCTCGAAAG \\
\hline$\# 16$ & $\mathrm{p} 2576 \mathrm{~F}$ & GC GAATTC GCATGC GGGACAGTCGCGAGTCAGC \\
\hline$\# 17$ & p2576R & GC GGATCC GGCGCTCTCCCGCAAGACAG \\
\hline$\# 18$ & 2577EK & CG GGTACC C GGTCATCGGGGGGAGCCG \\
\hline$\# 19$ & $2576 \mathrm{Ef}$ & CG GAATTC ATGAACGATCCGATCCGTC \\
\hline$\# 20$ & BADNsiIF & ACGGATGGCCTTTATGCATTTCTACAAACT \\
\hline$\# 21$ & CM132RCy5 & Су5-СTTCCACAGTAGTTCACCACC \\
\hline$\# 22$ & $2576 \mathrm{EXr}$ & CG CTCGAG GAAAAGCCCCGCCTCGTCG \\
\hline$\# 23$ & $2576 \mathrm{EBrS}$ & CG GGATCC GAAAAGCCCCGCCTCGTCG \\
\hline$\# 24$ & $2576 \mathrm{EBr}-\mathrm{S}$ & CG GGATCC C GCCGCGACGCACCGCCGGC \\
\hline$\# 25$ & $2578 \mathrm{EKf}$ & CG GAATTC ATGCCCACACCCGGCACGG \\
\hline$\# 26$ & 2578EKR & GC GGTACC GCTCCGTTCCAACCTGTAG \\
\hline$\# 27$ & $3694 \mathrm{ESf}$ & CG GAATTC ATGAGCGACCGTAACGTAC \\
\hline$\# 28$ & $3694 \mathrm{ESr}$ & AT GAGCTC AGACGGGTGATGTCTCCCT \\
\hline$\# 29$ & 5006Bf & GC GGATCC ATGAGACTGGCCGAACTGC \\
\hline$\# 30$ & 5006BSr & GA GAGCTC GGTGGTCGTCGCTTGTCGT \\
\hline$\# 31$ & 5006BSr-S & AT GAGCTC C AGCCCCGGCGGCGTCGCCGA \\
\hline$\# 32$ & 3694ESr-S & AT GAGCTC CTTTCACTTCCTGCGGGACT \\
\hline \multicolumn{3}{|c|}{ Primers used in RT-qPCR analysis } \\
\hline$\# 33$ & rpsLF & CTCGGCACTGCGTAAGGTAT \\
\hline$\# 34$ & rpsLR & TGTGCTCTTGCAGGTTGTGA \\
\hline \#35 & nadBF & CTACCTGGACATCAGCCACA \\
\hline$\# 36$ & nadBR & GGTAATGTCGATGCCGAAGT \\
\hline$\# 37$ & PA2576qF & CCTGGGAATCGTCCATACCG \\
\hline$\# 38$ & PA2576qR & CGCGACCGGATAGATGAAGG \\
\hline$\# 39$ & PA1698qF & GGAAAGCCAGCAGAAGCTC \\
\hline$\# 40$ & PA1698qR & GGAGAAGCCCTCCAGGTAAG \\
\hline$\# 41$ & PA3037qF & GACGAAAGCCTCGACCTGT \\
\hline$\# 42$ & PA3037qR & GTCGAGGGTGACGAACAGAC \\
\hline$\# 43$ & PA0807qF & CGACAACCTCAACGACACC \\
\hline \#44 & PA0807qR & GTAGTCGGGGAAGGTGAACA \\
\hline
\end{tabular}

\section{References}

1. Tani, T.H.; Khodursky, A.; Blumenthal, R.M.; Brown, P.O.; Matthews, R.G. Adaptation to Famine: A Family of Stationary-Phase Genes Revealed by Microarray Analysis. Proc. Natl. Acad. Sci. USA 2002, 99, 13471-13476. [CrossRef] [PubMed]

2. Kroner, G.M.; Wolfe, M.B.; Freddolino, P.L. Escherichia coli Lrp Regulates One-Third of the Genome via Direct, Cooperative, and Indirect Routes. J. Bacteriol. 2021, 201, e00411-18. [CrossRef] [PubMed]

3. Kölling, R.; Lother, H. AsnC: An Autogenously Regulated Activator of Asparagine Synthetase A Transcription in Escherichia coli. J. Bacteriol. 1985, 164, 310-315. [CrossRef] [PubMed]

4. Willins, D.A.; Ryan, C.W.; Platko, J.V.; Calvo, J.M. Characterization of Lrp, and Escherichia coli Regulatory Protein That Mediates a Global Response to Leucine. J. Biol. Chem. 1991, 266, 10768-10774. [CrossRef] 
5. Keuntje, B.; Masepohl, B.; Klipp, W. Expression of the putA Gene Encoding Proline Dehydrogenase from Rhodobacter capsulatus Is Independent of NtrC Regulation but Requires an Lrp-like Activator Protein. J. Bacteriol. 1995, 177, 6432-6439. [CrossRef] [PubMed]

6. Madhusudhan, K.T.; Huang, N.; Sokatch, J.R. Characterization of BkdR-DNA Binding in the Expression of the $b k d$ Operon of Pseudomonas putida. J. Bacteriol. 1995, 177, 636-641. [CrossRef] [PubMed]

7. Belitsky, B.R.; Gustafsson, M.C.; Sonenshein, A.L.; Von Wachenfeldt, C. An Lrp-like Gene of Bacillus subtilis Involved in BranchedChain Amino Acid Transport. J. Bacteriol. 1997, 179, 5448-5457. [CrossRef] [PubMed]

8. Inoue, H.; Inagaki, K.; Eriguchi, S.I.; Tamura, T.; Esaki, N.; Soda, K.; Tanaka, H. Molecular Characterization of the mde Operon Involved in L-Methionine Catabolism of Pseudomonas putida. J. Bacteriol. 1997, 179, 3956-3962. [CrossRef]

9. Friedberg, D.; Midkiff, M.; Calvo, J.M. Global versus Local Regulatory Roles for Lrp-Related Proteins: Haemophilus influenzae as a Case Study. J. Bacteriol. 2001, 183, 4004-4011. [CrossRef]

10. Yokoyama, K.; Ishijima, S.A.; Clowney, L.; Koike, H.; Aramaki, H.; Tanaka, C.; Makino, K.; Suzuki, M. Feast/Famine Regulatory Proteins (FFRPs): Escherichia coli Lrp, AsnC and Related Archaeal Transcription Factors. FEMS Microbiol. Rev. 2006, 30, 89-108. [CrossRef] [PubMed]

11. Cho, K.; Winans, S.C. The putA Gene of Agrobacterium tumefaciens Is Transcriptionally Activated in Response to Proline by an Lrp-like Protein and Is Not Autoregulated. Mol. Microbiol. 1996, 22, 1025-1033. [CrossRef]

12. Peekhaus, N.; Tolner, B.; Poolman, B.; Krämer, R. The Glutamate Uptake Regulatory Protein (Grp) of Zymomonas mobilis and Its Relation to the Global Regulator Lrp of Escherichia coli. J. Bacteriol. 1995, 177, 5140-5147. [CrossRef] [PubMed]

13. Koike, H.; Ishijima, S.A.; Clowney, L.; Suzuki, M. The Archaeal Feast/Famine Regulatory Protein: Potential Roles of Its Assembly Forms for Regulating Transcription. Proc. Natl. Acad. Sci. USA 2004, 101, 2840-2845. [CrossRef] [PubMed]

14. Thaw, P.; Sedelnikova, S.E.; Muranova, T.; Wiese, S.; Ayora, S.; Alonso, J.C.; Brinkman, A.B.; Akerboom, J.; van der Oost, J.; Rafferty, J.B. Structural Insight into Gene Transcriptional Regulation and Effector Binding by the Lrp/AsnC Family. Nucleic Acids Res. 2006, 34, 1439-1449. [CrossRef]

15. Leonard, P.M.; Smits, S.H.J.; Sedelnikova, S.E.; Brinkman, A.B.; de Vos, W.M.; van der Oost, J.; Rice, D.W.; Rafferty, J.B. Crystal Structure of the Lrp-like Transcriptional Regulator from the Archaeon Pyrococcus furiosus. EMBO J. 2001, 20, 990-997. [CrossRef] [PubMed]

16. Reddy, M.C.M.; Gokulan, K.; Jacobs, W.R.; Ioerger, T.R.; Sacchettini, J.C. Crystal Structure of Mycobacterium tuberculosis LrpA, a Leucine-Responsive Global Regulator Associated with Starvation Response. Protein Sci. 2008, 17, 159-170. [CrossRef] [PubMed]

17. Yamada, M.; Ishijima, S.A.; Suzuki, M. Interactions between the Archaeal Transcription Repressor FL11 and Its Coregulators Lysine and Arginine. Proteins 2009, 74, 520-525. [CrossRef] [PubMed]

18. De los Rios, S.; Perona, J.J. Structure of the Escherichia coli Leucine-Responsive Regulatory Protein Lrp Reveals a Novel Octameric Assembly. J. Mol. Biol. 2007, 366, 1589-1602. [CrossRef] [PubMed]

19. Yan, S.; Zhen, J.; Li, Y.; Huang, Y.; Ai, X.; Li, Y.; Stojkoska, A.; Huang, X.; Ruan, C.; Li, J.; et al. Mycobacterium Lrp/AsnC Family Transcriptional Factor Modulates the Arginase Pathway as Both a Sensor and a Transcriptional Repressor. J. Genet. Genom. 2021, 48, 1020-1031. [CrossRef] [PubMed]

20. Deng, W.; Wang, H.; Xie, J. Regulatory and Pathogenesis Roles of Mycobacterium Lrp/AsnC Family Transcriptional Factors. J. Cell. Biochem. 2011, 112, 2655-2662. [CrossRef] [PubMed]

21. Yokoyama, K.; Ishijima, S.A.; Koike, H.; Kurihara, C.; Shimowasa, A.; Kabasawa, M.; Kawashima, T.; Suzuki, M. Feast/Famine Regulation by Transcription Factor FL11 for the Survival of the Hyperthermophilic Archaeon Pyrococcus OT3. Structure 2007, 15, 1542-1554. [CrossRef] [PubMed]

22. Ashworth, J.; Plaisier, C.L.; Lo, F.Y.; Reiss, D.J.; Baliga, N.S. Inference of Expanded Lrp-like Feast/Famine Transcription Factor Targets in a Non-Model Organism Using Protein Structure-Based Prediction. PLoS ONE 2014, 9, e107863. [CrossRef] [PubMed]

23. Bartosik, A.A.; Glabski, K.; Jecz, P.; Mikulska, S.; Fogtman, A.; Koblowska, M.; Jagura-Burdzy, G. Transcriptional Profiling of parA and parB Mutants in Actively Dividing Cells of an Opportunistic Human Pathogen Pseudomonas aeruginosa. PLoS ONE 2014, 9, e87276. [CrossRef]

24. Galán-Vásquez, E.; Luna, B.; Martínez-Antonio, A. The Regulatory Network of Pseudomonas aeruginosa. Microb. Inform. Exp. 2011, 1, 3. [CrossRef] [PubMed]

25. Balasubramanian, D.; Schneper, L.; Kumari, H.; Mathee, K. A Dynamic and Intricate Regulatory Network Determines Pseudomonas aeruginosa Virulence. Nucleic Acids Res. 2013, 41, 1-20. [CrossRef] [PubMed]

26. Chou, H.T.; Kwon, D.-H.; Hegazy, M.; Lu, C.-D. Transcriptome Analysis of Agmatine and Putrescine Catabolism in Pseudomonas aeruginosa PAO1. J. Bacteriol. 2008, 190, 1966-1975. [CrossRef] [PubMed]

27. He, W.; Li, C.; Lu, C.-D. Regulation and Characterization of the DadRAX Locus for D-Amino Acid Catabolism in Pseudomonas aeruginosa PAO1. J. Bacteriol. 2011, 193, 2107-2115. [CrossRef]

28. Knoten, C.A.; Hudson, L.L.; Coleman, J.P.; Farrow, J.M.; Pesci, E.C. KynR, a Lrp/AsnC-Type Transcriptional Regulator, Directly Controls the Kynurenine Pathway in Pseudomonas aeruginosa. J. Bacteriol. 2011, 193, 6567-6575. [CrossRef] [PubMed]

29. Lasocki, K.; Bartosik, A.A.; Mierzejewska, J.; Thomas, C.M.; Jagura-Burdzy, G. Deletion of the parA (soj) Homologue in Pseudomonas aeruginosa Causes ParB Instability and Affects Growth Rate, Chromosome Segregation, and Motility. J. Bacteriol. 2007, 189, 5762-5772. [CrossRef] 
30. Bartosik, A.A.; Mierzejewska, J.; Thomas, C.M.; Jagura-Burdzy, G. ParB Deficiency in Pseudomonas aeruginosa Destabilizes the Partner Protein ParA and Affects a Variety of Physiological Parameters. Microbiology 2009, 155, 1080-1092. [CrossRef]

31. Brinkman, A.B.; Ettema, T.J.G.; Vos, W.M.D.; Oost, J.V.D. The Lrp Family of Transcriptional Regulators. Mol. Microbiol. 2003, 48, 287-294. [CrossRef] [PubMed]

32. Winsor, G.L.; Griffiths, E.J.; Lo, R.; Dhillon, B.K.; Shay, J.A.; Brinkman, F.S.L. Enhanced Annotations and Features for Comparing Thousands of Pseudomonas Genomes in the Pseudomonas Genome Database. Nucleic Acids Res. 2016, 44, D646-D653. [CrossRef] [PubMed]

33. Mirdita, M.; Ovchinnikov, S.; Steinegger, M. ColabFold-Making Protein Folding Accessible to All. bioRxiv 2021. [CrossRef]

34. Waterhouse, A.; Bertoni, M.; Bienert, S.; Studer, G.; Tauriello, G.; Gumienny, R.; Heer, F.T.; de Beer, T.A.P.; Rempfer, C.; Bordoli, L.; et al. SWISS-MODEL: Homology Modelling of Protein Structures and Complexes. Nucleic Acids Res. 2018, 46, W296-W303. [CrossRef]

35. Guex, N.; Peitsch, M.C.; Schwede, T. Automated Comparative Protein Structure Modeling with SWISS-MODEL and SwissPdbViewer: A Historical Perspective. Electrophoresis 2009, 30, S162-S173. [CrossRef] [PubMed]

36. Yan, Y.; Tao, H.; He, J.; Huang, S.-Y. The HDOCK Server for Integrated Protein-Protein Docking. Nat. Protoc. 2020, 15, 1829-1852. [CrossRef]

37. Karimova, G.; Pidoux, J.; Ullmann, A.; Ladant, D. A Bacterial Two-Hybrid System Based on a Reconstituted Signal Transduction Pathway. Proc. Natl. Acad. Sci. USA 1998, 95, 5752-5756. [CrossRef] [PubMed]

38. Brinkman, A.B.; Dahlke, I.; Tuininga, J.E.; Lammers, T.; Dumay, V.; de Heus, E.; Lebbink, J.H.; Thomm, M.; de Vos, W.M.; van Der Oost, J. An Lrp-like Transcriptional Regulator from the Archaeon Pyrococcus furiosus Is Negatively Autoregulated. J. Biol. Chem. 2000, 275, 38160-38169. [CrossRef] [PubMed]

39. Kawalek, A.; Glabski, K.; Bartosik, A.A.; Fogtman, A.; Jagura-Burdzy, G. Increased ParB Level Affects Expression of Stress Response, Adaptation and Virulence Operons and Potentiates Repression of Promoters Adjacent to the High Affinity Binding Sites parS3 and parS4 in Pseudomonas aeruginosa. PLoS ONE 2017, 12, e0181726. [CrossRef]

40. Juan, C.; Moyá, B.; Pérez, J.L.; Oliver, A. Stepwise Upregulation of the Pseudomonas aeruginosa Chromosomal Cephalosporinase Conferring High-Level Beta-Lactam Resistance Involves Three AmpD Homologues. Antimicrob. Agents Chemother. 2006, 50, 1780-1787. [CrossRef] [PubMed]

41. Lindberg, F.; Lindquist, S.; Normark, S. Inactivation of the AmpD Gene Causes Semiconstitutive Overproduction of the Inducible Citrobacter freundii Beta-Lactamase. J. Bacteriol. 1987, 169, 1923-1928. [CrossRef]

42. Bonamore, A.; Boffi, A. Flavohemoglobin: Structure and Reactivity. IUBMB Life 2008, 60, 19-28. [CrossRef]

43. Salamov, V.S.A.; Solovyevand, A. Automatic Annotation of Microbial Genomes and Metagenomic Sequences. In Metagenomics and Its Applications in Agriculture, Biomedicine and Environmental Studies; Li, R.W., Ed.; Nova Science Publishers: Hauppauge, NY, USA, 2011; pp. 61-78.

44. Karimova, G.; Gauliard, E.; Davi, M.; Ouellette, S.P.; Ladant, D. Protein-Protein Interaction: Bacterial Two-Hybrid. In Bacterial Protein Secretion Systems; Humana Press: New York, NY, USA, 2017; pp. 159-176. [CrossRef]

45. Mitura, M.; Lewicka, E.; Godziszewska, J.; Adamczyk, M.; Jagura-Burdzy, G. Alpha-Helical Protein KfrC Acts as a Switch between the Lateral and Vertical Modes of Dissemination of Broad-Host-Range RA3 Plasmid from IncU (IncP-6) Incompatibility Group. Int. J. Mol. Sci. 2021, 22, 4880. [CrossRef]

46. Kusiak, M.B. Molecular and Structural Analysis of parB Gene of Pseudomonas aeruginosa. Ph.D. Thesis, Department of Microbial Biochemistry IBB PAS, Warsaw, Poland, 2010.

47. Delucia, A.M.; Six, D.A.; Caughlan, R.E.; Gee, P.; Hunt, I.; Lam, J.S.; Dean, C.R. Lipopolysaccharide (LPS) Inner-Core Phosphates Are Required for Complete LPS Synthesis and Transport to the Outer Membrane in Pseudomonas aeruginosa PAO1. mBio 2011, 2, e00142-11. [CrossRef]

48. Perumal, D.; Sakharkar, K.R.; Tang, T.H.; Chow, V.T.K.; Lim, C.S.; Samal, A.; Sugiura, N.; Sakharkar, M.K. Cloning and Targeted Disruption of Two Lipopolysaccharide Biosynthesis Genes, $k d s A$ and waaG, of Pseudomonas aeruginosa PAO1 by Site-Directed Mutagenesis. J. Mol. Microbiol. Biotechnol. 2010, 19, 169-179. [CrossRef]

49. De Kievit, T.R.; Lam, J.S. Isolation and Characterization of Two Genes, waaC ( $r f a C)$ and waaF (rfaF), Involved in Pseudomonas aeruginosa Serotype O5 Inner-Core Biosynthesis. J. Bacteriol. 1997, 179, 3451-3457. [CrossRef]

50. Kumarevel, T.; Nakano, N.; Ponnuraj, K.; Gopinath, S.C.B.; Sakamoto, K.; Shinkai, A.; Kumar, P.K.R.; Yokoyama, S. Crystal Structure of Glutamine Receptor Protein from Sulfolobus tokodaii Strain 7 in Complex with Its Effector L-Glutamine: Implications of Effector Binding in Molecular Association and DNA Binding. Nucleic Acids Res. 2008, 36, 4808-4820. [CrossRef]

51. Kudo, N.; Allen, M.D.; Koike, H.; Katsuya, Y.; Suzuki, M. Crystallization and Secondary-Structure Determination of a Protein of the Lrp/AsnC Family from a Hyperthermophilic Archaeon. Acta Crystallogr. Sect. D Biol. Crystallogr. 2001, 57, 469-471. [CrossRef]

52. Marasco, R.; Varcamonti, M.; La Cara, F.; Ricca, E.; De Felice, M.; Sacco, M. In Vivo Footprinting Analysis of Lrp Binding to the ilvIH Promoter Region of Escherichia coli. J. Bacteriol. 1994, 176, 5197-5201. [CrossRef]

53. Beloin, C.; Jeusset, J.; Revet, B.; Mirambeau, G.; Le Hégarat, F.; Le Cam, E. Contribution of DNA Conformation and Topology in Right-Handed DNA Wrapping by the Bacillus subtilis LrpC Protein. J. Biol. Chem. 2003, 278, 5333-5342. [CrossRef] [PubMed]

54. Dey, A.; Shree, S.; Pandey, S.K.; Tripathi, R.P.; Ramachandran, R. Crystal Structure of Mycobacterium tuberculosis H37Rv AldR (Rv2779c), a Regulator of the ald Gene. J. Biol. Chem. 2016, 291, 11967-11980. [CrossRef] 
55. Wang, Q.; Calvo, J.M. Lrp, a Major Regulatory Protein in Escherichia coli, Bends DNA and Can Organize the Assembly of a Higher-Order Nucleoprotein Structure. EMBO J. 1993, 12, 2495-2501. [CrossRef]

56. Suzuki, M. The DNA-Binding Specificity of Eubacterial and Archaeal FFRPs. Proc. Jpn. Acad. Ser. B 2003, 79B, 213-222. [CrossRef]

57. Wang, Q.; Sacco, M.; Ricca, E.; Lago, C.T.; De Felice, M.; Calvo, J.M. Organization of Lrp-Binding Sites Upstream of ilvIH in Salmonella typhimurium. Mol. Microbiol. 1993, 7, 883-891. [CrossRef]

58. Wang, Q.; Calvo, J.M. Lrp, a Global Regulatory Protein of Escherichia coli, Binds Co-Operatively to Multiple Sites and Activates Transcription of ilvIH. J. Mol. Biol. 1993, 229, 306-318. [CrossRef]

59. Nou, X.; Braaten, B.; Kaltenbach, L.; Low, D.A. Differential Binding of Lrp to Two Sets of Pap DNA Binding Sites Mediated by Pap I Regulates Pap Phase Variation in Escherichia coli. EMBO J. 1995, 14, 5785-5797. [CrossRef]

60. Liu, C.F.; Brandt, G.S.; Hoang, Q.Q.; Naumova, N.; Lazarevic, V.; Hwang, E.S.; Dekker, J.; Glimcher, L.H.; Ringe, D.; Petsko, G.A. Crystal Structure of the DNA Binding Domain of the Transcription Factor T-Bet Suggests Simultaneous Recognition of Distant Genome Sites. Proc. Natl. Acad. Sci. USA 2016, 113, E6572-E6581. [CrossRef]

61. Cirz, R.T.; O'Neill, B.M.; Hammond, J.A.; Head, S.R.; Romesberg, F.E. Defining the Pseudomonas aeruginosa SOS Response and Its Role in the Global Response to the Antibiotic Ciprofloxacin. J. Bacteriol. 2006, 188, 7101-7110. [CrossRef]

62. Wu, W.; Jin, S. PtrB of Pseudomonas aeruginosa Suppresses the Type III Secretion System under the Stress of DNA Damage. J. Bacteriol. 2005, 187, 6058-6068. [CrossRef]

63. Rietsch, A.; Vallet-Gely, I.; Dove, S.L.; Mekalanos, J.J. ExsE, a Secreted Regulator of Type III Secretion Genes in Pseudomonas aeruginosa. Proc. Natl. Acad. Sci. USA 2005, 102, 8006-8011. [CrossRef]

64. Allocati, N.; Federici, L.; Masulli, M.; Di Ilio, C. Glutathione Transferases in Bacteria. FEBS J. 2009, 276, 58-75. [CrossRef]

65. De Wind, N.; de Jong, M.; Meijer, M.; Stuitje, A.R. Site-Directed Mutagenesis of the Escherichia coli Chromosome near OriC: Identification and Characterization of AsnC, a Regulatory Element in E. coli Asparagine Metabolism. Nucleic Acids Res. 1985, 13, 8797-8811. [CrossRef]

66. Saier, M.H.; Tran, C.V.; Barabote, R.D. TCDB: The Transporter Classification Database for Membrane Transport Protein Analyses and Information. Nucleic Acids Res. 2006, 34, D181-D186. [CrossRef]

67. Västermark, Å.; Almén, M.S.; Simmen, M.W.; Fredriksson, R.; Schiöth, H.B. Functional Specialization in Nucleotide Sugar Transporters Occurred through Differentiation of the Gene Cluster EamA (DUF6) before the Radiation of Viridiplantae. BMC Evol. Biol. 2011, 11, 123. [CrossRef]

68. Franke, I.; Resch, A.; Daßler, T.; Maier, T.; Böck, A. YfiK from Escherichia coli Promotes Export of O-Acetylserine and Cysteine. J. Bacteriol. 2003, 185, 1161-1166. [CrossRef] [PubMed]

69. Rouanet, C.; Nasser, W. The PecM Protein of the Phytopathogenic Bacterium Erwinia chrysanthemi, Membrane Topology and Possible Involvement in the Efflux of the Blue Pigment Indigoidine. J. Mol. Microbiol. Biotechnol. 2001, 3, 309-318.

70. Hadley, B.; Litfin, T.; Day, C.J.; Haselhorst, T.; Zhou, Y.; Tiralongo, J. Nucleotide Sugar Transporter SLC35 Family Structure and Function. Comput. Struct. Biotechnol. J. 2019, 17, 1123-1134. [CrossRef]

71. Ghanei, H.; Abeyrathne, P.D.; Lam, J.S. Biochemical Characterization of MsbA from Pseudomonas aeruginosa. J. Biol. Chem. 2007, 282, 26939-26947. [CrossRef]

72. Williams McMackin, E.A.; Djapgne, L.; Corley, J.M.; Yahr, T.L. Fitting Pieces into the Puzzle of Pseudomonas aeruginosa Type III Secretion System Gene Expression. J. Bacteriol. 2019, 201, e00209-19. [CrossRef]

73. Diaz, M.; King, J.; Yahr, T. Intrinsic and Extrinsic Regulation of Type III Secretion Gene Expression in Pseudomonas aeruginosa. Front. Microbiol. 2011, 2, 89. [CrossRef]

74. Augustin, D.K.; Song, Y.; Baek, M.S.; Sawa, Y.; Singh, G.; Taylor, B.; Rubio-Mills, A.; Flanagan, J.L.; Wiener-Kronish, J.P.; Lynch, S.V. Presence or Absence of Lipopolysaccharide O Antigens Affects Type III Secretion by Pseudomonas aeruginosa. J. Bacteriol. 2007, 189, 2203-2209. [CrossRef] [PubMed]

75. Sambrook, J.; Fritsch, E.F.; Maniatis, T. Molecular Cloning: A Laboratory Manual; Cold Spring Harbor Laboratory Press: Cold Spring Harbor, NY, USA, 1989.

76. Irani, V.R.; Rowe, J.J. Enhancement of Transformation in Pseudomonas aeruginosa PAO1 by Mg2+ and Heat. BioTechniques 1997, 22, 54-56. [CrossRef]

77. Miller, J.H. Experiments in Molecular Genetics; Cold Spring Harbor Laboratory: Cold Spring Harbor, NY, USA, 1972; ISBN: 978-0-87969-106-6.

78. Rashid, M.H.; Kornberg, A. Inorganic Polyphosphate Is Needed for Swimming, Swarming, and Twitching Motilities of Pseudomonas aeruginosa. Proc. Natl. Acad. Sci. USA 2000, 97, 4885-4890. [CrossRef]

79. Kotecka, K.; Kawalek, A.; Kobylecki, K.; Bartosik, A.A. The MarR-Type Regulator PA3458 Is Involved in Osmoadaptation Control in Pseudomonas aeruginosa. Int. J. Mol. Sci. 2021, 22, 3982. [CrossRef]

80. Pfaffl, M.W. A New Mathematical Model for Relative Quantification in Real-Time RT-PCR. Nucleic Acids Res. 2001, 29, e45. [CrossRef] [PubMed]

81. Kawalek, A.; Bartosik, A.A.; Glabski, K.; Jagura-Burdzy, G. Pseudomonas aeruginosa Partitioning Protein ParB Acts as a NucleoidAssociated Protein Binding to Multiple Copies of a parS-Related Motif. Nucleic Acids Res. 2018, 46, 4592-4606. [CrossRef]

82. Modrzejewska, M.; Kawalek, A.; Bartosik, A.A. The LysR-Type Transcriptional Regulator BsrA (PA2121) Controls Vital Metabolic Pathways in Pseudomonas aeruginosa. mSystems 2021, 6, e00015-21. [CrossRef] [PubMed] 
83. Jagura-Burdzy, G.; Thomas, C.M. Purification of KorA Protein from Broad Host Range Plasmid RK2: Definition of a Hierarchy of KorA Operators. J. Mol. Biol. 1995, 253, 39-50. [CrossRef]

84. Zukowski, M.M.; Gaffney, D.F.; Speck, D.; Kauffmann, M.; Findeli, A.; Wisecup, A.; Lecocq, J.P. Chromogenic Identification of Genetic Regulatory Signals in Bacillus subtilis Based on Expression of a Cloned Pseudomonas Gene. Proc. Natl. Acad. Sci. USA 1983, 80, 1101-1105. [CrossRef]

85. Bradford, M.M. A Rapid and Sensitive Method for the Quantitation of Microgram Quantities of Protein Utilizing the Principle of Protein-Dye Binding. Anal. Biochem. 1976, 72, 248-254. [CrossRef]

86. Pawłowska, J.; Aleksandrzak-Piekarczyk, T.; Banach, A.; Kiersztyn, B.; Muszewska, A.; Serewa, L.; Szatraj, K.; Wrzosek, M. Preliminary Studies on the Evolution of Carbon Assimilation Abilities within Mucorales. Fungal Biol. 2016, 120, 752-763. [CrossRef]

87. Bochner, B.R.; Gadzinski, P.; Panomitros, E. Phenotype MicroArrays for High-Throughput Phenotypic Testing and Assay of Gene Function. Genome Res. 2001, 11, 1246-1255. [CrossRef]

88. Hanahan, D. Studies on Transformation of Escherichia coli with Plasmids. J. Mol. Biol. 1983, 166, 557-580. [CrossRef]

89. Simon, R.; Priefer, U.; Pühler, A. A Broad Host Range Mobilization System for in vivo Genetic Engineering: Transposon Mutagenesis in Gram Negative Bacteria. Bio/Technology 1983, 1, 784-791. [CrossRef]

90. Kawalek, A.; Kotecka, K.; Modrzejewska, M.; Gawor, J.; Jagura-Burdzy, G.; Bartosik, A.A. Genome Sequence of Pseudomonas aeruginosa PAO1161, a PAO1 Derivative with the ICEPae1161 Integrative and Conjugative Element. BMC Genom. 2020, 21, 14. [CrossRef]

91. Kovach, M.E.; Phillips, R.W.; Elzer, P.H.; Roop, R.M.; Peterson, K.M. PBBR1MCS: A Broad-Host-Range Cloning Vector. BioTechniques 1994, 16, 800-802. [PubMed]

92. Ludwiczak, M.; Dolowy, P.; Markowska, A.; Szarlak, J.; Kulinska, A.; Jagura-Burdzy, G. Global Transcriptional Regulator KorC Coordinates Expression of Three Backbone Modules of the Broad-Host-Range RA3 Plasmid from IncU Incompatibility Group. Plasmid 2013, 70, 131-145. [CrossRef]

93. El-Sayed, A.K.; Hothersall, J.; Thomas, C.M. Quorum-Sensing-Dependent Regulation of Biosynthesis of the Polyketide Antibiotic Mupirocin in Pseudomonas fluorescens NCIMB 10586. Microbiol. Read. Engl. 2001, 147, 2127-2139. [CrossRef]

94. Spratt, B.G.; Hedge, P.J.; te Heesen, S.; Edelman, A.; Broome-Smith, J.K. Kanamycin-Resistant Vectors That Are Analogues of Plasmids PUC8, PUC9, PEMBL8 and PEMBL9. Gene 1986, 41, 337-342. [CrossRef]

95. Marx, C.J.; Lidstrom, M.E. Development of Improved Versatile Broad-Host-Range Vectors for Use in Methylotrophs and Other Gram-Negative Bacteria. Microbiol. Read. Engl. 2001, 147, 2065-2075. [CrossRef]

96. Thorsted, P.B.; Shah, D.S.; Macartney, D.; Kostelidou, K.; Thomas, C.M. Conservation of the Genetic Switch between Replication and Transfer Genes of IncP Plasmids but Divergence of the Replication Functions Which Are Major Host-Range Determinants. Plasmid 1996, 36, 95-111. [CrossRef] [PubMed]

97. Lukaszewicz, M.; Kostelidou, K.; Bartosik, A.A.; Cooke, G.D.; Thomas, C.M.; Jagura-Burdzy, G. Functional Dissection of the ParB Homologue (KorB) from IncP-1 Plasmid RK2. Nucleic Acids Res. 2002, 30, 1046-1055. [CrossRef]

98. Bartosik, A.A.; Glabski, K.; Jecz, P.; Lasocki, K.; Mikosa, M.; Plochocka, D.; Thomas, C.M.; Jagura-Burdzy, G. Dissection of the Region of Pseudomonas aeruginosa ParA That Is Important for Dimerization and Interactions with Its Partner ParB. Microbiol. Read. Engl. 2014, 160, 2406-2420. [CrossRef] 